\title{
Reinvigorating Trade and Inclusive Growth
}




\section{Reinvigorating Trade and Inclusive Growth}




\section{CONTENTS}

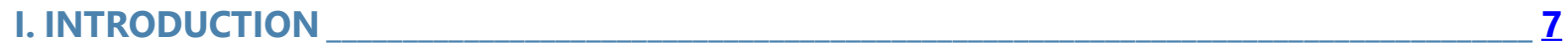

II. TRADE AREAS WITH HIGH GROWTH POTENTIAL ___________________________

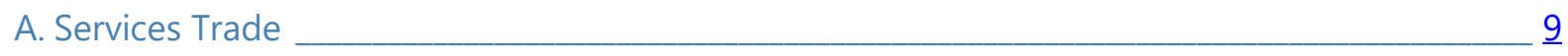

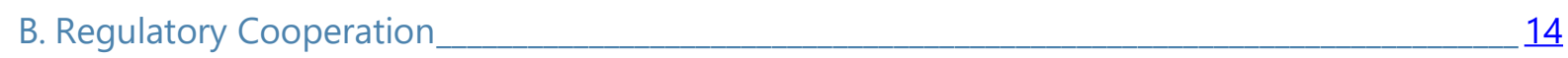

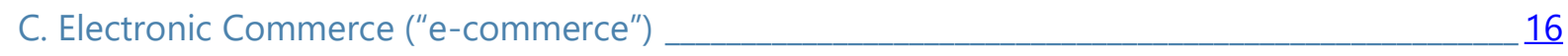

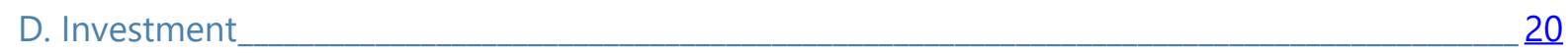

E. Market Access for Merchandise Trade_______ $\underline{22}$

III. TRADE-RELATED POLICIES FOR INCLUSIVENESS_________ $\underline{\mathbf{2 5}}$

A. Trade and the Empowerment of Poor People____ 25

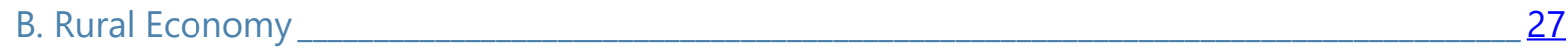

C. Micro, Small, and Medium-Sized Enterprises_______ $\underline{28}$

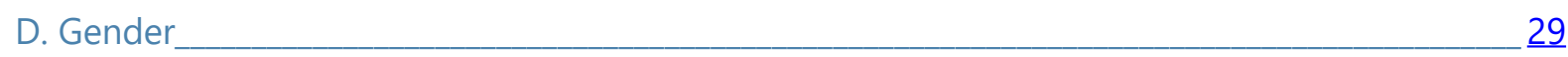

E. Complementary Policies to Support Inclusiveness__________ 31

IV. ROLE OF THE INTERNATIONAL TRADING SYSTEM ______ $\underline{\mathbf{3 2}}$

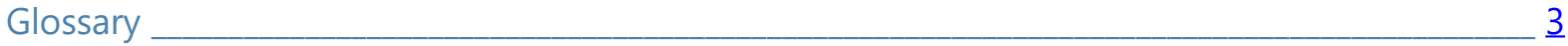

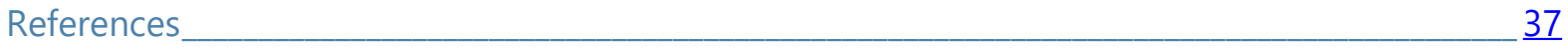

\section{BOXES}

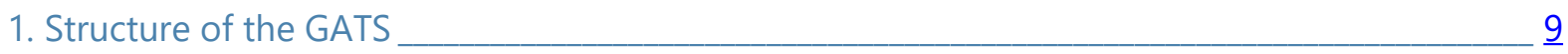

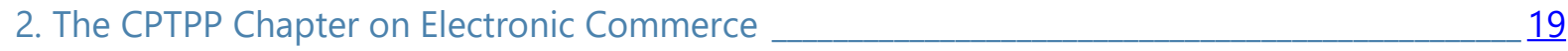

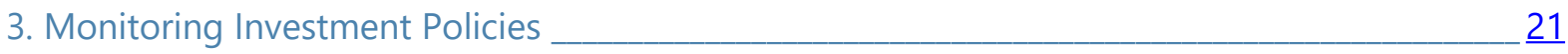

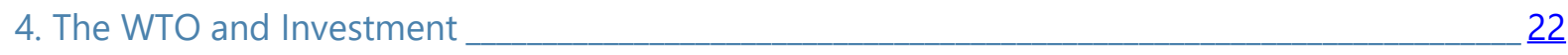

5. Benefits from Market Access Reforms: Examples_________ 24

6. Fisheries Subsidies Negotiations at the WTO________ $\underline{28}$

7. GATT/WTO: Selected Experience with Alternative Negotiating Approaches______ $\underline{36}$

\section{FIGURES}

1. Sector Shares in Total World Value-Added and Gross Exports ______ 10

2. Ratio of Value-Added to Gross Exports for the World, by Sector_______ 11

3. Changes in Regulatory Heterogeneity by Sector 2014-17______ 15

4. Tariffs Have Come Down but Reform Stalled Since the Early 2000s____ $\underline{23}$

5. RTAs in Force, 1948-2018_________ 34 


\section{Glossary}

\begin{tabular}{|c|c|}
\hline$A E$ & Advanced economy \\
\hline AGP & Agreement on Government Procurement (WTO) \\
\hline APEC & Asia Pacific Economic Cooperation Forum \\
\hline ASCM & Agreement on Subsidies and Countervailing Measures (WTO) \\
\hline BIT & Bilateral investment treaty \\
\hline BoP & Balance of payments \\
\hline CETA & Comprehensive Economic and Trade Agreement (Canada, EU) \\
\hline CPTPP & Comprehensive and Progressive Agreement for Trans-Pacific Partnership \\
\hline DDA & Doha Development Agenda (Doha Round) (WTO) \\
\hline EMDC & Emerging market and developing country \\
\hline EU & European Union \\
\hline FDI & Foreign direct investment \\
\hline FTA & Free trade agreement \\
\hline G-20 & Group of 20 \\
\hline GATS & General Agreement on Trade in Services (WTO) \\
\hline GTA & Global Trade Alert \\
\hline GVC & Global value chain \\
\hline$\| A$ & International investment agreement \\
\hline ISDS & Investor-state dispute settlement \\
\hline IT & Information technology \\
\hline ITA & Information Technology Agreement (WTO) \\
\hline MAl & Multilateral Agreement on Investment \\
\hline MC-11 & WTO $11^{\text {th }}$ Ministerial Conference (2017) \\
\hline MFN & Most favored nation \\
\hline MSME & Micro, small, and medium-sized enterprise \\
\hline NAFTA & North American Free Trade Agreement \\
\hline NTB & Non-tariff barrier \\
\hline NTM & Non-tariff measure \\
\hline OECD & Organization for Economic Cooperation and Development \\
\hline PTA & Preferential trade agreement \\
\hline RTA & Regional trade agreement \\
\hline SME & Small and medium-sized enterprise \\
\hline SPS & Sanitary and Phyto-sanitary \\
\hline STRI & Services Trade Restrictiveness Index \\
\hline TAA & Trade Adjustment Assistance \\
\hline TBT & Technical barriers to trade \\
\hline TFA & Trade Facilitation Agreement (WTO) \\
\hline TiSA & Trade in Services Agreement \\
\hline TPP & Trans-Pacific Partnership \\
\hline TRIMS & Agreement on Trade-Related Investment Measures (WTO) \\
\hline UNCITRAL & United Nations Commission on International Trade Law \\
\hline UNCTAD & United Nations Conference on Trade and Development \\
\hline WEO & World Economic Outlook (IMF) \\
\hline WTO & World Trade Organization \\
\hline
\end{tabular}




\section{EXECUTIVE SUMMARY}

Trade integration can play a much larger role in boosting shared prosperity. The current focus on trade tensions threatens to obscure the great untapped benefits possible from further trade reform. The opportunities provided by information technology and other fundamental changes in the global economy are yet to be reflected in modern areas of trade policy, such as services and electronic commerce. Greater openness in these areas would promote competition, lift productivity, and raise living standards. In many other areas, such as the rural economy, smaller enterprises, and women's economic empowerment, trade-related reforms are important particularly to foster more inclusive growth.

Harnessing flexible approaches to WTO negotiations may be the key to reinvigorating global trade reform. Despite the benefits at stake-and with important exceptions such as the WTO Trade Facilitation Agreement-trade reform has lagged since the early 2000s. For much of this period, governments focused their efforts in the WTO on a single negotiating approach. Now, as groups of WTO members pursue joint initiatives in several areas, attention is turning to how other negotiating approaches-including some used effectively in the past-can be leveraged so that trade once again plays its full role in driving increased global economic prosperity.

Building greater, more durable openness-this paper's focus-should be part of a broader effort to strengthen and reinvest in the global trading system. The system of global trade rules that has nurtured unprecedented economic growth across multiple generations faces tensions. Though only recently brought to the fore, those tensions are rooted in issues that have been left unresolved for too long. Governments need to promptly address outstanding questions involving, for example, the WTO dispute system and the reach of subsidy disciplines. Cooperative action to secure greater openness - an imperative in its own right - could also help to resolve these issues.

$* * * * * * * * *$

The opening of trade after World War II through the early 2000 s lifted living standards and reduced poverty, but remains incomplete. Tariffs fell sharply, starting with advanced economies, but then also emerging market and developing economies. For example, developing (advanced) economies cut their average tariffs from 31 percent (10 percent) in 1980 to 9 percent (4 percent) in 2015. An ever-deepening rules-based system—notably under the GATT and WTO—brought more openness, transparency, and stability. Much of this reflects reform up to the early 2000s. However, tariffs, regulatory differences, and other policy barriers still impede trade in goods. And even as trade agreements increasingly extend behind the border, domestic policies still often distort trade.

Fundamental changes in newer areas of the global economy are not being reflected in global trade policy, stifling future prosperity. Services comprise two-thirds of global GDP and employment, and (on a value-added basis) nearly half of global trade, yet barriers to services trade today are roughly as high as those to trade in goods a half century ago. Digital technologies make more services tradable across borders. Trade and investment decisions are increasingly 
complements, rather than substitutes, yet policy barriers still obstruct much FDI and the lack of a common template for thousands of international investment agreements creates a spaghetti bowl of provisions for investors and governments. The rise of global value chains and trade in inputs lends added importance to regulatory co-operation, trade and investment facilitation, and enabling policy environments for private sector innovation.

Trade can also be a powerful force for more inclusive growth, including by lowering poverty and by opening opportunities to small firms, farmers, and fishermen, as well as women. Better trade policies, notably in the area of e-commerce, could help small firms to export. But traditional areas of trade policy are also important. Distortions to agricultural trade impact market access and food price volatility, affecting both poor farmers and poor consumers. Limiting fisheries subsidies could help to secure the livelihoods of coastal communities and the sustainability of fish stocks. In all of these areas trade helps to drive female employment and economic empowerment. However, given the potential for trade and other structural change to create adjustment pressures for certain sectors, groups or regions, triggering discontent among some segments of society, it is also important to have in place appropriate complementary policies.

The path forward needs to heed the hard lessons of nearly two decades of WTO negotiations and to recognize a more complex trade policy landscape. The slow pace of reforms since the early 2000s, fundamental changes in a more interconnected modern economy, and the risk of trade policy reversals call for urgency to reinvigorate trade policy reforms. The WTO institutional and legal framework, and its near-global membership, have unique advantages. Yet reliance on an approach in which all members must agree on all issues risks driving negotiating activity outside the WTO. Agreeing among so many members, each with unique challenges and priorities, has proven difficult.

More flexible negotiating approaches have been effective in the past. The multilateral trading system has not always relied on large-scale 'single undertakings' like the Uruguay Round. When the WTO was created in 1995 many expected it would foster a flow of new agreements on various topics. The history of the GATT and WTO shows that many approaches have been deployed over the years - some fully multilateral, and others not. Key parts of the current WTO rule book were initially agreed by and applied (in the 1970s and 1980s) only to those countries adopting the Tokyo Round "Codes." The 1996 Information Technology Agreement (ITA) and its 2016 expansion are examples in which a "critical mass" of WTO members agreed tariff cuts they then apply to imports from all WTO members. Disciplines on government procurement-otherwise outside WTO rules-apply only among participants in that agreement, but the agreement is open to non-participants as wellwhich would not necessarily be true if the agreement were done outside the WTO.

Flexible approaches could help to advance reforms in the areas discussed in this paper. On top of actions to open economies unilaterally, reforms are ideally advanced through fully multilateral agreements among all WTO members. But where that is not initially possible, advancing within the WTO system through other approaches, including plurilaterals, has often been seen as preferable by many WTO members compared to advancing outside the system. What is important is that initiatives using flexible negotiating approaches attract a diverse and representative set of members, are open to all, and serve to strengthen the global trading system. 
At their July 2017 meeting in Hamburg G20 leaders emphasized how open investment and trade promote growth, productivity, jobs, and development. They called for advancing strong, sustainable, balanced and inclusive growth and expressed their determination to shape globalization to better enable people to seize the opportunities it provides. This paper supports that ambition. It begins by exploring the potential for reforms in certain areas to significantly impact aggregate economic outcomes like productivity and income levels. It then discusses other areas of reform that bear primarily on inclusiveness. This sets up a discussion in the latter part of the paper on how cooperative reforms can be achieved. The role of domestic policies in a healthy adjustment to trade and technology - a focus in a recent joint paper (IMF, WB, WTO 2017)—remains important; this paper updates the earlier coverage, including with new evidence at the national level. 


\section{INTRODUCTION}

1. Despite a recent rebound in trade, a prolonged slowdown in the pace of trade reform is leaving in place widespread trade distortions and putting at risk the strength and durability of the global economic recovery. A global economic upswing that began around mid-2016 grew into a synchronized expansion underpinned by trade-intensive investment growth. But this largely cyclical development, and a more recent period of unusually high trade tensions-which itself poses serious concerns-risk masking the need for substantial and durable trade opening on a global basis. Remaining trade distortions are a key factor behind the trade tensions, making the need to reinvigorate trade reform all the more urgent. ${ }^{1}$

\section{As new trade reform initiatives lagged and the benefits of past reforms levelled off,} trade growth slowed. Global trade volumes grew at some 7 percent annually during the 1990sdouble the rate of global GDP growth-but decelerated markedly as the ratio of trade growth to GDP growth fell to 1.5 during 2001-07 and to unity in the period after $2008 .^{2}$ While several factors lie behind the slowdown, a substantial part represents a slower pace of trade reform following the remarkable progress made from the 1980 s to the early 2000 s.

3. It is time to reinvest in open, rules-based global trade. Since World War II a system of global trade rules has brought more openness, stability, and transparency to trade, nurturing unprecedented world economic growth. It is time to reinvest in that system to serve the modern economy. To think that the work of trade reform is essentially complete is a fallacy that neglects both the significant remaining obstacles to traditional trade and the opportunities presented by the rise in services and technology for greater trade-driven prosperity. This is the focus of the sections that discuss areas with high potential for growth (Section II) and inclusiveness (Section III).

\section{Extending rules-based trade openness poses new challenges and could require fresh}

thinking and exploring all available approaches. At the domestic level, trade policy and trade negotiations increasingly reach "behind the border" and interact with domestic regulatory agencies, sectoral ministries, and sub-national entities. Unlike a classical tariff-cutting exercise, for example, successfully opening to services trade brings additional complexities: policy coherence becomes critical in designing and implementing reform. For any particular trade policy areas it follows that some countries may be prepared to move more quickly than others. So internationally, it's important to channel that desire in ways that are most constructive for the countries concerned, while also contributing to a healthy global system. This is the focus of Section IV.

\footnotetext{
${ }^{1}$ The uptick in trade restrictions after the global financial crisis and recent tensions recall an adage coined by Jagdish Bhagwati as the "bicycle theory" and explained by U.S. Trade Representative Zoellick as: "If the trade liberalization process does not move forward, it will, like a bicycle, be pulled down by the political gravity of special interests."

2 Examining the period after the global financial crisis, IMF (2016a) concludes that non-cyclical factors dragged down global merchandise trade growth by $13 / 4$ percentage points a year during 2012-15.
} 
5. This paper complements earlier joint work. Along with the broad benefits of trade, IMFWB-WTO (2017) emphasized policy tools that can be used to help workers and communities to adjust to adjustment pressures associated with trade and technological change. The current paper digs more deeply into the benefits that trade and trade reform can provide for economic growth and inclusiveness and how such reform could be achieved at the global level.

\section{TRADE AREAS WITH HIGH GROWTH POTENTIAL}

6. Reinvigorating trade integration should be a key component of the global policy agenda to boost economic growth. Despite the upswing that began in 2016, a longer-term trade slowdown has coincided with weaker productivity growth. This has occurred because the benefits of past major trade policy reforms have played out and new initiatives have lagged. ${ }^{3}$ The pace of new trade policy reforms at the global level has slowed since 2001; this has not only left an unfinished agenda in traditional areas, but has also meant that the trading system has not kept pace with modern economic developments. At the same time, new trade restrictions imposed since the global financial crisis have begun to weigh on global trade; this trend has only grown recently.

\section{Certain "frontier" areas of trade policy have high potential to lift global productivity} and durably increase medium-term growth. The digital economy revolution is opening new opportunities for cross-border trade and investment (Meltzer, 2016). This is changing the nature of trade, elevating the roles of policies relating to electronic commerce ("e-commerce"), ${ }^{4}$ investment, and services trade. This reflects the international nature of supply chains and complementarity of foreign direct investment (FDI) with trade in goods and services-the 'trade-investment-services' nexus (Richard Baldwin). The effectiveness of this nexus, and of international supply chains, is also grounded in secure property rights, including for intellectual property. The growing overlap between trade regimes and domestic policy puts extra emphasis on effective regulatory cooperation.

8. While the benefits are high in these areas, so too are the risks. International rules in these areas are less developed than those in the more traditional areas of trade. Moreover, broadly speaking the existing international obligations - whether in the WTO or in other trade and investment agreements-provide limited protection against backsliding from existing policies. This is also an important consideration, particularly in an environment of rising trade tensions.

\section{Policymaking and international rules in these areas are already linked. The WTO} General Agreement on Trade in Services (GATS), for example, addresses many aspects of investment in service sectors. Countries' GATS commitments also apply to the digital delivery of services, and the GATS provides a built-in mechanism for the pursuit of regulatory cooperation on services.

\footnotetext{
${ }^{3}$ Developing countries' unilateral reforms in the 1980s/90s and such initiatives as EU expansions, the conclusion of the Uruguay Round (1994) and creation of the WTO, and China's WTO accession (2001) strengthened the global trade policy landscape and promoted the growth of global value chains.

${ }^{4}$ Electronic commerce includes goods and services produced, distributed, marketed, sold, or delivered through electronic means.
} 
10. A trade policy agenda to promote global growth should also encompass market access issues and other conventional areas of trade policy. Much remains to be done to promote open and secure market access in the goods sector. The work of reducing tariffs is incomplete, while greater transparency and openness in government procurement markets can promote competition and increase expenditure quality and efficiency, particularly important when budgets are tight.

\section{A. Services Trade}

11. Trade policy lags far behind the evolution of the services sector in the global economy. Services comprise some two-thirds of global GDP and employment. Yet the limited opening of service sectors to foreign competition impedes trade and productivity growth throughout the sector and the broader economy. As innovation further shapes which services can be traded across borders (Box 1, GATS Mode 1) it is becoming even more important to address obstacles to that trade. It is also important that countries open up to international competition in services provided in other ways, including through foreign direct investment and the operation of foreign affiliates (relating to GATS Mode 3), and the temporary movement of workers ("natural persons") across borders for the purpose of supplying services (GATS Mode 4).

\section{Box 1. Structure of the GATS}

The GATS applies to the international provision of services through four modes of supply. These are: Cross-border supply (Mode 1), similar to the concept of merchandise trade;

- Consumption abroad (Mode 2), the supply of a service in the territory of one WTO member to a consumer of another member (often associated with tourism)_policies in this area are generally open;

- Commercial presence (Model 3), the supply of a service to consumers in another (host) member by establishing a commercial presence, a concept closely linked to FDI and the operation of foreign affiliates; and

- $\quad$ Presence of natural persons (Mode 4), involving the supply of a service by an individual of one member temporarily present in the territory of another member.

Certain GATS obligations apply automatically across the service sector and to all modes of supply; these include the obligation to treat services and service suppliers from any WTO member no less favorably compared to those from any other WTO member ("MFN"). "Market access" (the absence of six, mostly 'quota-type' limitations) and "national treatment" (treating foreign services and service suppliers no less favorably than domestic services and service suppliers) are commitments specific to the member, to the service sector, and to the mode of supply (and subject to any limitations contained in the member's schedule). The GATS schedules now in force are, largely, those agreed in the Uruguay Round or, for newer WTO members, those agreed in the accession negotiations.

12. Improved access to services from trade reform promotes economy-wide productivity and income growth. Given the sector's size, the role of services productivity in overall economic performance is evident. Less appreciated, though, is the interplay between services reform and manufacturing performance. Services comprise significant shares of the value added of all sectors in the economy, and this is reflected also in trade figures: while only a quarter of global trade is traded as services, on a value-added basis half of the value of global trade originates in service sectors 
(Figures 1 and 2). ${ }^{5}$ In an illustrative scenario, Beverelli and others (2017) find that full services trade liberalization could raise manufacturing productivity by an average of 22 percent across a sample of 57 countries, with larger benefits for countries with stronger institutional environments.

Figure 1. Sector Shares in Total World Value-Added and Gross Exports

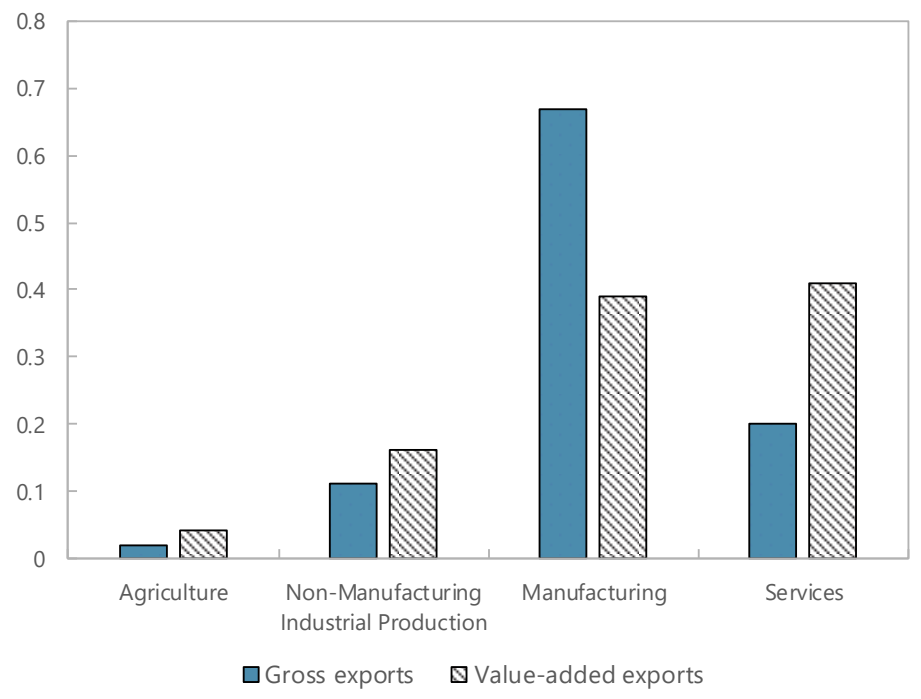

Source: Johnson (2014), using the World Input-Output Database (WIOD). Data are for 2008.

\section{Country studies provide compelling evidence that openness in services contributes to} long run growth performance (Hoekman and Mattoo, 2008). India's reforms in the 1990s brought more openness, better regulation, and greater investment, allowing Indian manufacturing firms to source services from a range of domestic and foreign providers operating in a more competitive environment. Manufacturers' access to better, more reliable, and more diverse business services enhanced firms' ability to invest in new opportunities and technologies, to concentrate production in fewer locations, to efficiently manage inventories, and to coordinate decisions with suppliers and customers. Arnold and others (2016) studied the experience of 4,000 manufacturing firms during the period of services reforms and concluded that procompetitive reforms in banking, insurance, telecommunications, and transport boosted the productivity of both foreign and locally-owned manufacturing firms. ${ }^{6}$ Other empirical studies reinforce these findings, but also stress the importance of well-designed reforms accompanied by sound domestic regulation.

\footnotetext{
${ }^{5}$ The fact that the value of direct trade in services is smaller than the value of services embodied in traded goods might reflect, in part, that the costs of trading services is generally much higher than the cost of trading goods (Fiorini and Hoekman, 2017). IMF (2018b) documents the rising role of service inputs in manufacturing.

${ }^{6}$ Specifically, a one-standard-deviation increase in the aggregate index of services liberalization was associated with a productivity increase of 12 percent for domestic firms and 13 percent for foreign firms. The largest additional effect was for transport reforms, followed by telecommunications and banking reforms.
} 


\section{Despite the economic importance of competitive service sectors, indicators point to policy barriers to services trade much higher than those affecting trade in goods. While} estimates of ad valorem equivalents for services trade are more uncertain than those for goods trade, ${ }^{7}$ OECD (2017) concludes that "[e]mpirical analysis reveals that the costs of services trade and investment barriers are high, largely exceeding the average tariff on traded goods, and that these costs apply to all modes of supplying services abroad." ${ }^{8}$ Within the wide divergences, estimates of 20 to 40 percent are common, with some much higher. The trade costs of concern include both those policies that explicitly target foreign suppliers, but also costs arising from domestic regulatory practices that fall short of best practice in competition and rule-making and may thus de facto discriminate against foreign suppliers.

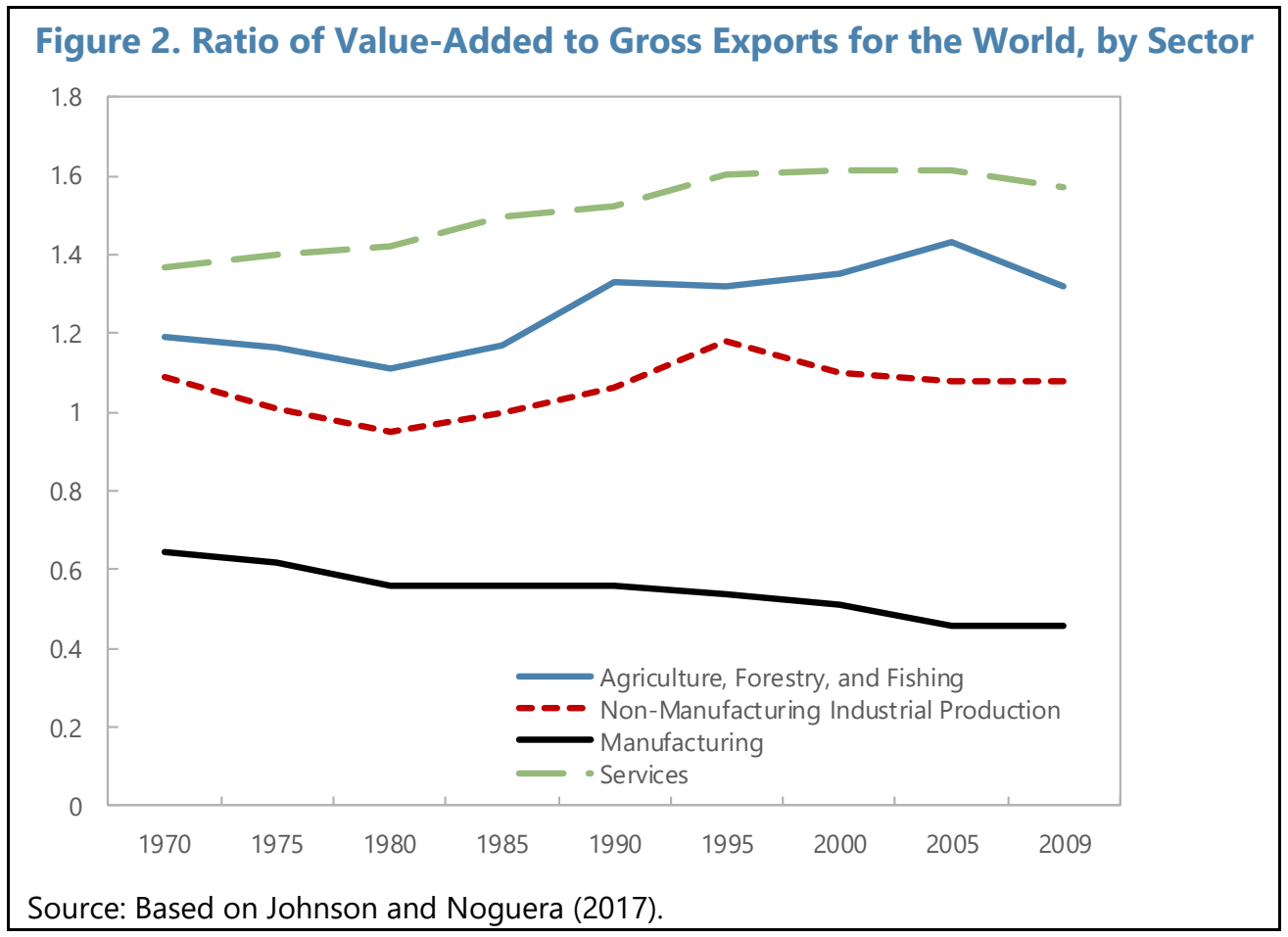

\footnotetext{
${ }^{7}$ Analysis of services trade continues to face difficulty in separating the policy-based costs from other costs of trading services. Nonetheless, the cross-country variation in services trade costs suggests that the policy component is a major factor. Miroudot, Sauvage and Shepherd (2013) and Koske and others (2015) provide evidence that barriers to trade and investment, and behind-the-border barriers to entry, are higher for service than for goods sectors.

${ }^{8}$ Compared to the rich information on policies affecting trade in goods, information on trade policy for services remains limited. Two mutually supportive initiatives are helping to address this gap. The OECD Services Trade Restrictiveness Index (STRI) covers 44 countries and 22 sectors; its database of laws and regulations is updated annually and now covers 2014-2017. STRI indices quantify restrictions on foreign entry and the movement of people, barriers to competition, regulatory transparency, and other discriminatory measures that impact the ease of doing business. Details are at: http://www.oecd.org/tad/services-trade/services-trade-restrictiveness-index.htm. The World Bank Services Trade Restrictions Database (http://iresearch.worldbank.org/servicetrade) covers 103 countries and 18 sectors in basic telecommunications, distribution, financial services, selected professional services, and transport; it covers the relevant modes of service delivery for covered sectors. The information was collected in $2008-10$ and has been updated for some countries, with 2016 updates forthcoming. Cerdeiro and Nam (2018) discuss the complexities of measuring services trade restrictions and the development of tariff-equivalent measures for such restrictions.
} 
15. Sound domestic regulation has a particular role in the service sector. Ranging from prudential regulation in financial and professional services to pro-competitive regulation in a variety of network-based services, sound domestic regulation is critical to realizing the benefits of services liberalization. Devising and implementing such regulation is not easy and there are acute regulatory problems especially but not just in developing countries (Mattoo and Sauvé, 2003). Regulatory institutions can be costly and may require sophisticated skills. To some extent such costs can be reduced by regional cooperation and recovered through fees-but external assistance could help ensure that adequate regulation is in place.

\section{Services trade liberalization has been negotiated multilaterally as well as in regional,} plurilateral, and bilateral contexts. The first multilateral services trade negotiations took place in the context of the Uruguay Round, resulting in the General Agreement on Trade in Services (GATS) in 1995 (Box 1). The GATS brings a critical framework for provisions on services trade but (with some exceptions) by and large the Uruguay Round outcome did not lead to significant liberalization. In the Doha Round, services negotiations aimed to improve the GATS and to deepen country-specific GATS commitments, but were made dependent on negotiations in other areas; ${ }^{9}$ offers were exchanged but little negotiating progress was made. ${ }^{10}$

17. Regional agreements have delivered only limited liberalization. The negotiations toward the Trans-Pacific Partnership (later, the CPTPP) were, however, more ambitious than most. Gootiiz and Mattoo (2014) find that the CPTPP commitments would enhance transparency and policy certainty compared to current GATS commitments. While explicit liberalization would be limited to selected sectors and countries, they also find that the TPP negotiating process may have induced changes in applied policies over the course of the negotiations. ${ }^{11}$ Moreover, some commitments would require liberalization several years after the completion of the agreement, for example by Vietnam in telecommunications and retail services, and by Malaysia in financial services.

\section{A high-ambition agenda to open services trade could promote greater competition} and productivity throughout the sector. Commentators such as Low (2016) and Hufbauer and others (2012) suggest several areas where progress could be made.

- Addressing gaps between GATS commitments and actual policy, possibly with standstill and "roll back" provisions (as in many regional agreements) to discourage policy reversals.

- Deepening and expanding specific commitments under the GATS to promote greater openness across a broad range of service industries and across multiple modes of supply.

\footnotetext{
${ }^{9}$ Hufbauer and others (2012) point to a "stunning neglect of services" in the Doha Round.

${ }^{10}$ Borchert and others (2011) conclude that Doha Round offers in the areas of distribution, financial, professional, telecommunications, and transport services would not generally have protected against backsliding, let alone prompted further significant opening of service sectors.

${ }^{11}$ For example Mexico's telecommunications policy was reformed in 2013, and Malaysia carried out several reforms between 2009 and 2013 in financial services, professional services, and telecommunications.
} 
- Where needed, identifying vehicles to promote capacity building to assist governments in helping to develop vigorous service sectors, as well as advice and support for service sector reforms more generally.

\section{One reason for limited negotiated liberalization thus far has been the inability to} address concerns about international market failure. These concerns range from matters of financial regulation and data privacy, to monopolistic practices and irregular immigration. A form of "negotiating tunnel vision" in trade negotiations has led to a focus solely on reciprocal marketopening, rather than on creating or promoting the (regulatory and other) preconditions for liberalization. Greater international cooperation involving regulators is needed to deliver both liberalization and enforceable agreements, and to improve the framework for services trade in such areas as government procurement in services, trade-distorting subsidies in the service sector, crossborder data flows, and mutual recognition of credentials in the area of professional services.

\section{Progress on services trade reform has been slow-despite the risk of backsliding on} current levels of openness and the potential for large benefits from greater openness-but some efforts have been made. International commitments on services trade remain limited. ${ }^{12}$ GATS (Article XIX) also requires WTO members to "enter into successive negotiations, beginning [in 2000] and periodically thereafter, with a view to achieving a progressively higher level of liberalization." This negotiating mandate was integrated into the broader Doha Round in 2001 but fell victim to disagreements over agriculture and other issues (Adlung, 2015). Services provisions in regional agreements that go beyond the GATS have helped to narrow the gap between commitments and applied policies, but-with some important exceptions and innovations-have not generally led to new liberalization. ${ }^{13}$ Though currently stalled, negotiations among over 20 economies (including the EU) toward a Trade in Services Agreement (TiSA) have been undertaken outside the WTO framework, but many of the participants have indicated a desire to eventually bring any results inside the WTO in order to build on the existing GATS commitments. There are also specific recent efforts on services within the WTO. ${ }^{14}$

\footnotetext{
12 According to Adlung and Mamdouh (2018), existing commitments under the GATS were mostly established during the Uruguay Round, remain "generally very shallow" and have not kept up with new trading opportunities made possible by technical innovations. Negotiations among a critical mass of WTO members on telecommunications and financial services soon after the establishment of the WTO delivered "commercially relevant" outcomes and were implemented in 1998 by participants on an MFN basis (that is, with respect to trade with all WTO members). Two decades on, negotiations on services trade rules mandated in the GATS itself have delivered no concrete results.

13 See, for example, Gootiiz and Mattoo (2017) on CPTPP services commitments.

14 At the 2017 WTO Ministerial Conference a group of 32 advanced and developing WTO Members called upon all Members to intensify work to conclude the negotiation of disciplines on domestic regulation of services in advance of the next Ministerial Conference. In addition, 71 WTO Members agreed to initiate exploratory work towards a future WTO negotiations on trade-related aspects of electronic commerce, including services trade aspects of the e-commerce agenda.
} 


\section{B. Regulatory Cooperation}

\section{Regulatory cooperation takes on increased importance in a world of global value} chains and complex production relationships. ${ }^{15}$ Unnecessary divergences in product regulations segment markets and impose a heavy burden on trade, and trade agreements increasingly seek to limit those costs while respecting differences in regulatory objectives. Regulatory diversity is a common source of trade tensions, suggesting also the importance of transparency and dialogue. Like some of the other areas highlighted in this paper, regulatory cooperation requires strong coordination within national governments and internationally-in this case, joining the trade and the regulatory communities. Also like some of the other areas, the ideal of regulatory cooperation at the fully global level can be challenging; progress among countries with similar objectives and capacities is valuable, however, especially if done under the WTO umbrella, such as through equivalence agreements.

\section{Regulatory cooperation operates through several channels to lowers costs and} increase competition. Cooperation mechanisms may range from harmonization (through the development and adoption of international standards and their use as a common basis for domestic regulations), mutual recognition, consultation and information exchange, and conformity assessment procedures. Provisions for transparency and process, such as consultation periods and the ability of foreign entities to comment on proposed regulatory changes, minimize trade tensions and build trust and confidence between trading partners and their regulators. At the WTO, governments have stressed that regulatory cooperation between Members is an effective means of disseminating good regulatory practices (WTO, 2011a,b).

\section{Regulatory cooperation has increased the volume and variety of products traded. An} empirical analysis of EU goods trade found that a 1 percent increase in the use of internationally harmonized standards increased product variety by 0.3 percent (Shepherd, 2007); harmonization also increased the number of U.S. firms entering the EU market and their trade volumes (Reyes, 2011). However, improved cooperation is needed to further reduce trade cost. In services, the trade costs associated with regulatory differences are estimated as equivalent to tariffs of 20 to 75 percent (Nordås, 2016). Moreover, substantial variations remain across service sectors in terms of cooperation convergence (Figure 3). ${ }^{16}$

\footnotetext{
15 International regulatory cooperation is usually interpreted broadly. An OECD working definition refers to "cooperation in the design, monitoring, enforcement, or ex-post management of regulation" (OECD, 2013). While useful to consider regulatory cooperation in a trade context, it can be pursued in trade agreements, or separately.

16 The figure shows changes in regulatory heterogeneity in service sectors across 35 OECD and 9 non-OECD countries, covering regulatory barriers ranging from restriction on foreign entry, lack of regulatory transparency, barriers to competition, to restriction on movement of people (based on the OECD Services Trade Restrictiveness Index). From 2014 to 2017, across 20 sectors 42 percent of country pairs saw their services regulations converge, 41 percent diverged, and 17 percent stayed the same. Convergence was greatest for logistics, and least for architecture.
} 


\section{Governments can pursue regulatory cooperation through various approaches.}

Autonomous actions include the application of good regulatory practices relating to transparency, consultation with domestic and foreign stakeholders, tools to assess regulatory alternatives (e.g., regulatory impact assessment), and domestic coordination and oversight of regulatory quality. ${ }^{17}$ Where international standards exist, the application of those standards at national level is an important step. In regional trade agreements (RTAs), regulatory co-operation provisions tend to be strongest when undertaken among countries with similar regulatory objectives and capacities; examples include NAFTA and the Australia-New Zealand Closer Economic Relations Trade Agreement. The EU-China Regulatory Cooperation Framework and the mutual recognition agreement between China and New Zealand, facilitating conformity assessment procedures for electronics, are examples of mechanisms adopted among more heterogenous players.

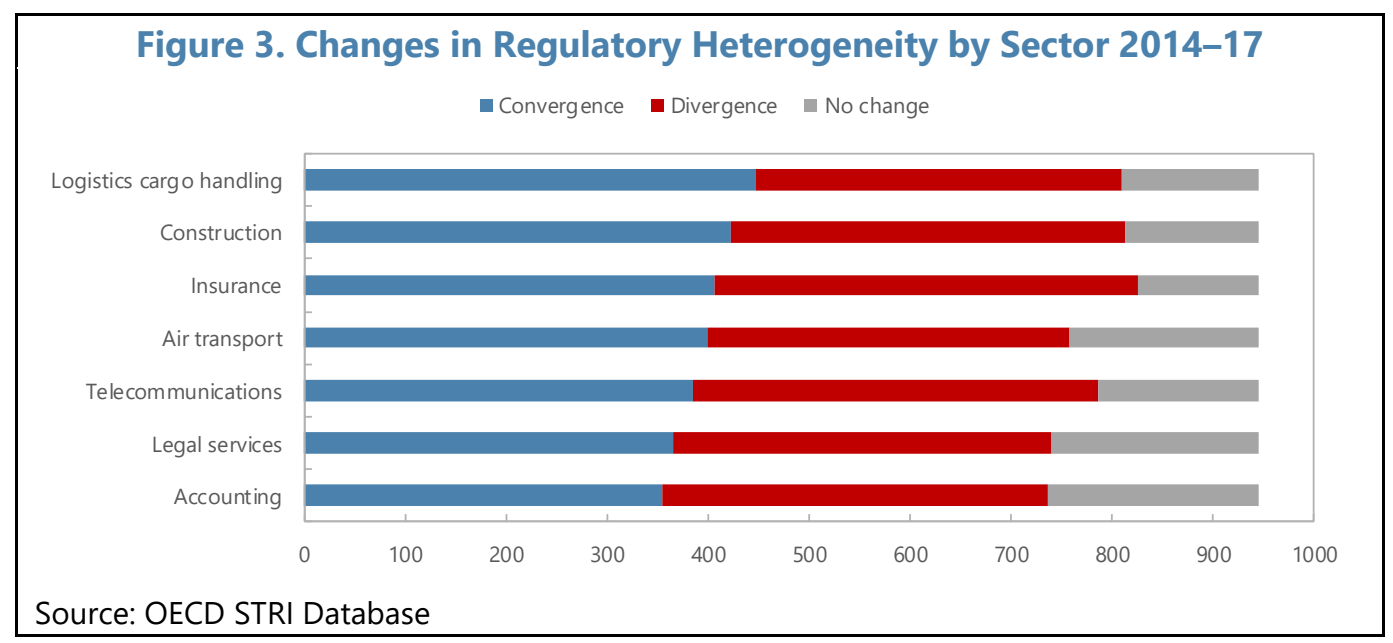

25. WTO Agreements contain very substantive disciplines on product regulations that collectively promote regulatory cooperation. The GATT national treatment and most-favorednation (MFN) obligations prohibit domestic tax and regulatory discrimination against imported goods, subject to exceptions for certain regulatory purposes (Sykes, 2017). The Agreements on Technical Barriers to Trade (TBT) and Sanitary and Phyto-sanitary Measures (SPS) were adopted by all WTO members at the conclusion of the Uruguay Round. ${ }^{18}$ They contain various additional provisions (beyond simply 'non-discrimination') for product regulations and standards, and conformity assessment procedures, including provisions that strongly encourage that such measures be the least trade-restrictive means possible to fulfil a particular legitimate objective or to address a

\footnotetext{
17 Autonomous approaches reduce regulatory costs and serve to facilitate the application of regulatory cooperation mechanisms. As they tend to focus on national objectives they are not necessarily intended to promote regulatory convergence.

18 The SPS Agreement applies to measures aimed to protect human, animal, and plant life or health from certain risks associated with trade in foods and beverages, feedstuffs, or the spreading of pests, among others. The TBT Agreement applies to product regulations and standards addressing a broad variety of legitimate objectives (except those expressly listed by the SPS Agreement), including consumer information, human and animal health, the protection of the environment, and national security. Before the advent of the WTO, domestic regulations were specifically disciplined by a GATT agreement, the so-called 1979 "Standards Code." However, as a "plurilateral agreement" the Standards Code was only acceded to by a subset of GATT "contracting parties" (members).
} 
particular risk. Transparency provisions require the notification of draft regulations and the opportunity for stakeholders to comment on the drafts. The WTO bodies that administer these agreements also serve as fora where concerns about draft and adopted regulations can be raised, discussed, and potentially resolved-providing a meaningful element of regulatory cooperation.

\section{Further efforts to promote regulatory cooperation could bring substantial benefits.}

Important areas include greater transparency in the formulation of regulations, greater involvement of domestic and foreign stakeholders in formulating measures, and the establishment of more fora in which discussions and further commitments can occur (Mavroidis, 2016). As in services and some other 'frontier' areas of trade reform, a key challenge in high quality regulatory cooperation is the sectoral diversity in regulatory approaches and issues (e.g., vehicles and pharmaceuticals)-a complexity that is also faced by businesses operating in these industries.

\section{Electronic Commerce ("e-commerce")}

\section{Open electronic commerce that respects legitimate regulatory priorities is} fundamental to modern economies. Promoting greater openness by reducing unnecessary impediments to e-commerce, and through cooperative efforts to facilitate it, can be expected to bring substantial economic benefits. Yet e-commerce also raises other important policy issues. For example, privacy, law enforcement, or national security considerations might lead a government to restrict the outward transfer of some data. To ensure prompt access to financial data, a regulator might require that certain data be maintained within its legal jurisdiction. Governments may also face pressure to restrict data flows or to require local data storage in order to favor domestic firms or industries.

\section{As economies go digital, the benefits of e-commerce are rising. ${ }^{19}$ Digitization affects} how goods and services are produced, traded, delivered, and consumed. E-commerce is used by businesses to expand customer bases and supply networks: globally, business-to-business ("B-to-B") e-commerce reached $\$ 23.9$ trillion in 2016 (USITC, 2017). ${ }^{20}$ Digitalization allows development of new markets (e.g., cloud computing) and business models, such as post-sale digital services that complement the sale of equipment (e.g., digital monitoring of equipment usage and operating environments to guide efficient repair and replacement). Digital technology makes cross-border trade possible for some services that previously required the service provider and consumer to be in

\footnotetext{
${ }^{19}$ BEA (2018) estimates that in 2016 the digital economy accounted for 6.5 percent (\$1.2 trillion) of U.S. GDP and employed 5.9 million people. By raising productivity and lowering trade costs, e-commerce is reckoned to have increased annual U.S. GDP by some 3.4 to 4.8 percent as of 2011 (USITC, 2014). Falk and Hagsten (2015) credit e-commerce for 17 percent of EU labor productivity growth from 2003 to 2010. Such investigations into the impact of e-commerce build on seminal work of Freund and Weinhold $(2002,2004)$ on the impact of the internet on trade in services and on trade in goods.

${ }^{20}$ This compares to an estimated $\$ 3.7$ trillion in business-to-consumer e-commerce (USITC 2017). B-to-B e-commerce is important to global value chains (GVCs); the networks that underpin GVCs depend on coordinated supply and purchasing actions by different firms in the network, operating in real time, and with substantial costs for delays and unpredictability. For instance, by adopting electronic data interchange technology and standards a foreign supplier can automate communications and transactions with its clients to integrate into their value chain.
} 
the same proximity; depending on domestic regulatory frameworks, this has opened to cross-border trade certain types of engineering, financial, and professional services, among others.

\section{Appropriate standards and regulation can facilitate the emergence of new forms of} international trade. A strong regulatory framework could include tools that facilitate remote transactions, such as electronic documents and e-signature; promote consumer protection, including online dispute resolution; enhance transparency and predictability in the digital environment, with clear rules on liability of digital platforms for traded goods and services; and protect privacy and personal information (World Bank, 2018). International regulatory cooperation can help to facilitate e-commerce. Regulators are cooperating to ensure appropriate levels of privacy with limited impact on e-commerce's economic and trade potential.

\section{E-commerce relies on cross-border information flows and is especially affected by} rules on the handling, processing, storage, and transfer of data. As efficient production and trade-and global value chains-increasingly rely on cross-border data flows, adequate data policies must balance businesses' need for access to global data with domestic goals such as those regarding privacy and law enforcement. ${ }^{21}$ Divergent country-specific regulations on privacy protection, for example, raise costs of e-commerce. For instance, even with the relatively harmonized system of the EU, a common problem for traditional e-commerce remains the fragmentation of national rules on data protection, whereby key concepts like "personal data" and forms of consent differ across countries (Kommerskollegium, 2015). ${ }^{22}$ A concerted international effort to adopt a coherent framework that protects personal data while fostering global e-commerce could help.

\section{A key challenge is to address legitimate public policy concerns without unduly} restricting e-commerce. The potential for tension between international data flows and divergent national privacy standards has provoked two types of international responses: regulatory cooperation and the negotiation of trade rules (Mattoo and Meltzer, 2018).

\section{Strengthening existing WTO agreements could help to promote e-commerce. The} GATS, for example, provides rules relevant to cross-border data transfers, but a clearer understanding is needed. For instance, the cross-border delivery of services (or Mode 1), one mode of services supply under the GATS, includes the international transmission of data that embodies the delivery of a service. This suggests that measures requiring the domestic storage or processing of data may already be covered by WTO obligations when WTO members have undertaken relevant specific commitments in their GATS schedules. The GATS also allows WTO Members to deviate from their WTO obligations for legitimate policy concerns, including the protection of privacy and

\footnotetext{
${ }^{21}$ Data flows have important roles in managing disperse production processes, facilitating collaboration on research and design, and managing supply chains and logistics networks, becoming "a means of production ... and the means through which some services are traded and GVCs are organized" (López-González and Jouanjean, 2017). Restrictions on data flows may impede these activities.

22 Illustrating the complex issues involved, this study argued that as transactions in the internal EU market may be enabled through data storage and processing outside the EU, barriers to the free movement of data to third countries can impact the free movement of goods and services within the internal market.
} 
personal data; however, questions may exist about the scope and coverage of such exceptions. The WTO Work Program on Electronic Commerce and the Joint Statement on Electronic Commerce (an initiative of now 72 WTO Members) are other important avenues for advancing work in this context. Clarifying the scope of current rules, and adding new rules where necessary, would go far in promoting a coherent and comprehensive multilateral framework for e-commerce.

\section{Improved trade policies can enhance the spread of goods through e-commerce.}

De minimis threshold values for customs shipments (below which packages are exempt from duty) vary greatly across countries, with lower thresholds requiring the calculation and collection of customs duties on low-value shipments, burdening disproportionately small e-commerce exporters. One can imagine concerted action by a range of countries to raise such de minimis levels, which some countries propose might also be done in the WTO.

\section{Full implementation of the WTO Trade Facilitation Agreement (TFA) can help to} promote goods trade through e-commerce. At the multilateral level, implementation of the TFA can reduce the paperwork burden on SME exporters of goods using e-commerce by making necessary information more available. Actions to make necessary customs information more easily available and to facilitate and expedite procedures for small consignments would reduce clearance times and other customs costs for SME goods exporters using e-commerce. Additionally, efficient transport and logistics services are needed to ensure the journey of e-commerce goods to the consumer or firm.

35. Bilateral and regional trade agreements offer some insights on potential global rules, as well as their limitations. The Comprehensive and Progressive Agreement for Trans-Pacific Partnership (CPTPP) features the most advanced rules to date on e-commerce, providing binding rules against the discriminatory treatment of digital products, on the cross-border transfer of data, and against server localization requirements, while recognizing the countries' ability to restrict data flows for privacy protection or other legitimate policy goals (Box 2). Other recent trade agreements have focused more on dialogue than on strict disciplines, such as the Canada - EU Comprehensive Economic and Trade Agreement (CETA), or have excluded the provisions from dispute settlement, such as the Australia - China Free Trade Agreement.

36. International agreements can ease the tradeoff between the free flow of data essential for international business and issues such as privacy. The key is to strike a balance between guaranteeing the protection of privacy (or other legitimate objectives) and ensuring that the flow of data is not restricted in a manner that unduly restricts trade. Attempts to find this balance may be found, for instance, in the EU-US Privacy Shield and the CPTPP.

\section{International instruments such as guidelines and declarations allow for more fine-} tuned discussions on regulatory principles, fostering greater coherence on e-commerce rules. Non-binding instruments offer like-minded countries a platform to agree on essential principles and policy goals that can guide domestic rules, while deferring the implementation to domestic considerations. International guidelines can hence promote best practices and reduce restrictions to 
e-commerce by providing greater detail in regulatory objectives and standards than that typically found in trade agreements. For instance, the APEC Privacy Framework of 2015 and OECD Guidelines on Protection of Privacy of 2013 help harmonize national privacy legislation while fostering international flows of data. The OECD Recommendation on Consumer Protection in E-Commerce provides similar guidance with regard to consumer protection rules. Other instruments offer greater level of detail, providing a basic template for domestic regulations, such as the UNCITRAL model laws for electronic signature and documents. Greater progress on these and similar initiatives can help policy makers in adopting regulatory frameworks that capture domestic policy concerns while promoting e-commerce through open and coherent regulations.

\section{Box 2. The CPTPP Chapter on Electronic Commerce}

The CPTPP Electronic Commerce chapter seeks to promote the free flow of data and prevent "localization requirements" of technologies and servers, while allowing the pursuit of legitimate public policy objectives. It includes disciplines ensuring that companies and consumers can access and move data freely (subject to safeguards, such as for privacy). CPTPP countries retain the ability to maintain and amend regulations related to data flows, including those oriented to protecting privacy, but have undertaken to do so in a way that does not create barriers to trade.

Also innovative is the prohibition against forcing businesses to build data storage centers or use local computing facilities in CPTPP markets. CPTPP countries have committed not to impose these kinds of 'localization' requirements on computing facilities, thus ensuring that information can travel across borders and business and consumers can benefit from the advantages of the "cloud."

Restrictions on data flows and localization requirements may be imposed for a "legitimate public policy objective," including the protection of privacy, to the extent that that measure is not a disguised restriction to trade, or that it imposed restrictions "greater than required" to achieve the desired policy objective.

Another new provision in the chapter is the prohibition of measures that force suppliers to share software source code with governments or commercial rivals when entering a CPTPP market.

Continuing the trend found in previous trade agreements, the chapter prohibits the imposition of customs duties on digital products, including products distributed electronically, such as software, music, video, e-books, and games. A similar provision prevents CPTPP countries from favoring national producers or suppliers of such products through measures such as discriminatory taxation or outright blocking or other forms of content discrimination.

To facilitate electronic commerce, the chapter includes provisions encouraging CPTPP Parties to promote paperless trading between businesses and the government, such as electronic customs forms; and providing for electronic authentication and signatures for commercial transactions. The agreement also requires CPTPP members to maintain a legal framework for electronic transactions consistent with the principles of the UNCITRAL Model Law on Electronic Commerce 1996 or the United Nations Convention on the Use of Electronic Communications in International Contracts.

To protect consumers, CPTPP members agree to adopt and maintain consumer protection laws related to fraudulent and deceptive commercial activities online and to ensure that privacy and other consumer protections can be enforced in CPTPP markets. Parties also are required to have measures to stop unsolicited commercial electronic messages (spam). The agreement recognizes that governments have different ways of implementing privacy protections, and CPTPP promotes interoperability between those diverse legal regimes. 


\section{Investment}

38. Foreign direct investment (FDI) is now a major driver of economic growth. As a vehicle of international commerce, estimated sales of FDI affiliates of $\$ 38$ trillion in 2016 exceeded global goods and services exports of $\$ 21$ trillion. ${ }^{23}$ Trade and FDI can be substitutes, particularly when barriers to trade are high, but trade and investment are also complements when a commercial presence is needed, and FDI barriers can then effectively serve as a barrier to trade. Studies associate the expansion of FDI since 1990 with a 20 percent increase in global GDP. ${ }^{24}$ Increased foreign investment is closely linked with the rise of regional and global value chains, which itself is facilitated by factors such as information technology and reduced shipping costs. In fact, most types of FDI are now seen as complements to trade, rather than as a substitute. Exports of foreign affiliates account for about a third of global goods and services exports (Cadestin and others, 2018). Accordingly, many governments have become more welcoming of FDI.

\section{Policy obstacles continue to hinder the establishment and subsequent operation of} foreign enterprises. Despite its importance, the establishment of foreign investments and the action of established foreign companies face discrimination and restrictions. Explicit restrictions can include foreign equity limitations, joint venture requirements and constraints on foreigners serving in senior management. Other types of significant policy distortions include tax or regulatory preferences for domestic investors, and conditioning the establishment or continued operation on export performance or the substitution of domestic over imported inputs. Certain types of investment screening are common and reasonable if implemented appropriately (e.g., national security); however, screening such as for 'economic needs' and any policies that reduce transparency and predictability tend to discourage investment. Monitoring efforts are bringing greater transparency to investment policies (Box 3).

\section{Current international governance of FDI is fragmented and complex. There are some} 3000 international investment agreements (IIAs), including bilateral investment treaties (BITs) and the investment provisions common in recent free trade agreements. While these agreements have brought greater openness and predictability, the overlap and lack of a common template results in a confusing landscape for governments as well as investors (Gonzalez, 2013). UNCTAD's report on

\footnotetext{
${ }^{23}$ UNCTAD WIR 2017 Table I.4. Sales include resale of purchased goods; using a somewhat different measurement concept, Cadestin and others (2018) report global gross output of foreign affiliates at some $\$ 20$ trillion. Relative to global GDP, global sales of foreign affiliates rose from 22 percent in 1990 to 50 percent in 2016. Global value added of foreign affiliates rose from 4.6 percent of global GDP in 1990 to an estimated 11.1 percent in 2016.

24 Hufbauer and Draper (2016). They also cite econometric estimates by Bill Cline (2010) as evidence that the growth of FDI in recent decades has contributed 1.1 percent a year in additional growth in advanced economies, and 1.4 percent a year in additional growth in developing countries.
} 
Reforming the International Investment Regime ${ }^{25}$ highlights "growing unease" with the functioning of the system, which has triggered efforts to improve the system to reflect the modern economy.

\section{Box 3. Monitoring Investment Policies}

The OECD's FDI Regulatory Restrictiveness Index has brought greater transparency to many aspects of investment policy. It covers all G20 and OECD countries (and some others), examining four main types of FDI restrictions for 22 sectors: foreign equity limitations; screening or approval mechanisms; restrictions on the employment of foreigners as key personnel; and operational restrictions, such as on branching, capital repatriation, or land ownership. The OECD notes that additional policy factors not covered by the Index, such as state ownership in key sectors, can in practice also give rise to FDI entry barriers.

$\underline{\text { UNCTAD }}$ and OECD collaborate to report, semi-annually, on new investment measures taken by G20 countries. In addition to its tracking of trade policy measures, Global Trade Alert tracks liberalizing and restrictive FDI measures, as well as related policies such as local-sourcing requirements and localization incentives.

\section{A universal approach to investment could go far in setting holistic rules critical in a} world of regional and global value chains. Although a global deal was elusive in the past, ${ }^{26}$ greater experience with international investment agreements, a narrowing in the earlier "northsouth" divide on investment issues, and a greater focus by governments on facilitating investment flows suggests room for agreement in this area. An agreement could establish rules for investment facilitation that could further the transparency and predictability of investment measures, streamline and speed up investment processes, and foster international cooperation and best practices. ${ }^{27}$ The close relationship between investment and trade in the modern economy, the experience with the GATS and other WTO agreements, along with the WTO's near-universal membership and its uniquely strong institutional provisions are reasons why many WTO members are now calling for work on investment facilitation in the WTO. That work is being pursued under a joint initiative involving a group of WTO members (Box 4 and Section IV).

\footnotetext{
25 Strengthening systemic consistency is among the "reform challenges" cited in UNCTAD, 2015a, Chapter 4, "Reforming the International Investment Regime: An Action Menu." Others include promoting and facilitating investment, reforming investment dispute settlement, while safeguarding the right to regulate for pursuing sustainable development policies.

${ }^{26}$ Efforts in the 1990s for a Multilateral Agreement on Investment, facilitated by the OECD, were eventually halted.

27 Outside the WTO, some have also called for agreements that could provide for non-discriminatory treatment of established foreign investments, establish a framework under which governments can commit to opening to new investments in the goods sector, and provide for appropriate exceptions and flexibilities. There have also been calls to bring greater consistency to core standards for investor protection that now often found in bilateral investment treaties and some other international investment agreements.
} 


\section{Box 4. The WTO and Investment}

Several WTO agreements affect investment policy. Most importantly, the WTO GATS has important implications for investment in service sectors (see Box 1). Among the others, the Agreement on Subsidies and Countervailing Measures (ASCM) disciplines subsidies affecting trade in goods, including investment incentives. The Agreement on Trade-Related Investment Measures (TRIMS), also pertaining to measures that affect trade in goods, limits the sorts of conditions that can be placed on investments; for example, it precludes conditioning investment approvals on export performance or the use of domestically-produced over imported inputs (local content requirements).

Current Initiatives. A group of 70 WTO members, including advanced economies, emerging market economies, and low-income developing countries, has begun structured discussions aimed at developing a multilateral framework on investment facilitation. These discussions seek to identify and develop the elements of a framework for facilitating foreign direct investments that would improve the transparency and predictability of investment measures; streamline and speed up administrative procedures and requirements; and enhance international cooperation, information sharing, the exchange of best practices, and relations with relevant stakeholders, including dispute prevention. This builds on recent international efforts such as the formulation by the G20 during the 2016 Chinese Presidency of G20 Guiding Principles for Global Investment Policymaking. Interest has also been spurred by the success in concluding and bringing into effect, in 2017, the WTO Agreement on Trade Facilitation (Section IV).

\section{E. Market Access for Merchandise Trade ${ }^{28}$}

42. Tariffs and other market access barriers were reduced significantly in recent decades, but progress has slowed since the early 2000s. Advanced, and especially emerging economies have come far in opening their markets through unilateral liberalization and WTO commitments. In the early 1980s average tariffs stood at about 10 percent in advanced economies and 30 percent in emerging market and developing economies. Great strides were made in reducing these barriers in the last two decades of the twentieth century (Figure 4). With the slower pace of trade negotiations, however, many of the reductions in applied tariff rates have not been locked in through WTO tariff bindings, leaving the potential for backsliding.

\footnotetext{
${ }^{28}$ We include here access to government procurement, as well as tariffs on merchandise trade. Government procurement is an important part of most economies. It is not subject to WTO rules under the GATT and GATS, but (as discussed further below) is covered under a WTO plurilateral agreement in which many WTO members participate. Commitments under that agreement are enforceable through WTO dispute settlement.
} 


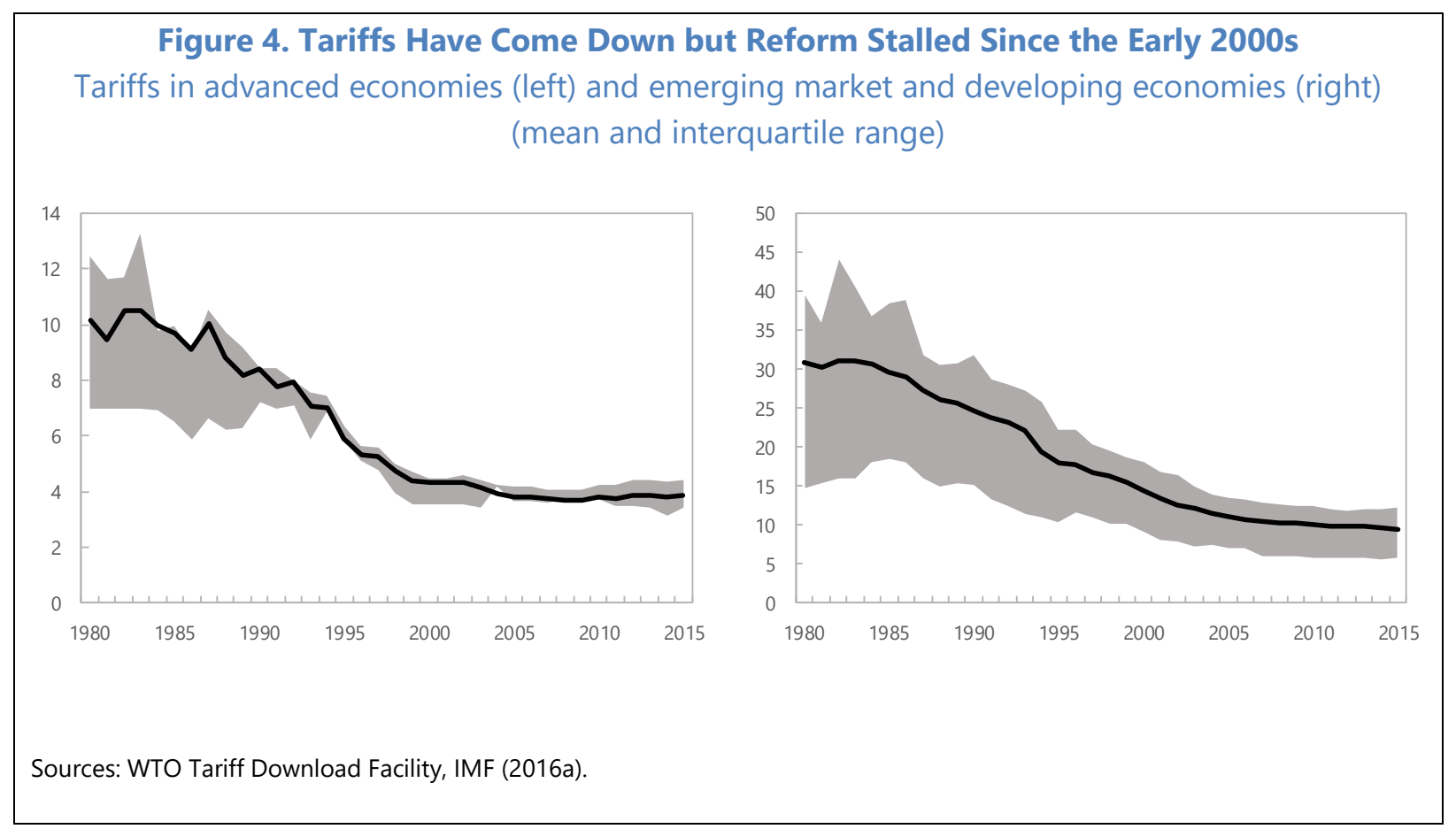

43. Market access conditions in agriculture remain a particular concern. Over 40 percent of WTO members apply agricultural tariffs that averaged more than 15 percent. ${ }^{29}$ In 2017, producer support (including the effects of market distortions, such as tariffs, as well as certain producer subsidies) is estimated to account on average for 18 percent of gross farm receipts in OECD countries, compared to 12 percent in a sample of 10 emerging economies (OECD, 2018).

\section{Further reductions in tariffs and other barriers to market access stand to boost} productivity and incomes. The economics is compelling (Box 5). Regarding downstream industries, Ahn and others (forthcoming) estimate that a 1 percentage point reduction in input tariffs in a sector improves total factor productivity in that sector by 2 percent. ${ }^{30}$ This operates in part through the impact of lower tariffs on the availability of new varieties of imported goods, including inputs. ${ }^{31}$ The benefits of tariff reductions for consumers are also remarkable, with lower prices and more choice disproportionately benefitting low-income consumers (Faijgelbaum and Khandelwal, 2016). ${ }^{32}$ Lifting non-tariff trade barriers and government procurement restrictions would bring similar effects.

${ }^{29}$ Calculations based on WTO "World Tariff Profiles, 2017."

30 The authors define "input tariff" as the average tariff a sector faces on all inputs, including those sourced locally. For a sector that imports one-fifth of its inputs, a 1 p.p. reduction in input tariffs requires an average 5 p.p. reduction in tariffs on its imported inputs.

31 Examining India's experience, Goldberg and others (2010) find that lower input tariffs account on average for 31 percent of the new products introduced by domestic firms.

32 They find that trade has reduced by one-quarter (two-thirds) the price of the household consumption basket of a typical advanced economy high income (low income) household. 
More open procurement markets for foreign suppliers raises the efficiency of public services (ADB, 2013).

\section{Box 5. Benefits from Market Access Reforms: Examples}

This box discusses three channels through which market access reforms can increase trade, reduce policy uncertainty, and bolster productivity.

Tariffs and productivity. Productivity gains from greater trade integration can arise from resources being reallocated to the most productive sectors, or through the adoption of more advanced technologies. In a study of Mercosur's impact, it has been estimated that each percentage point reduction in Brazil's tariffs increased Argentine firms' technology spending by between 1 and 1.5 percent (Bustos, 2011; see also WTO, 2017).

Tariff uncertainty and trade. Reducing the difference between applied and bound tariffs can have a very large impact on trade. Combined with sunk costs involved in entering a new foreign market, the uncertainty associated with these so-called 'tariff overhangs' can make firms delay entry decisions. Estimates using detailed Australian product-level data suggest that the impact of reducing both applied and bound rates to zero would increase the variety of traded products more than four times as much as if only applied rates were set to zero (Handley, 2014). In addition, increasing the number of bound duties (to cover tariff lines that currently remain 'unbound') would also be important.

Non-tariff barriers and trade. A wide range of NTBs remain, substantially affecting trade. For instance, a oneday customs delay has been estimated to decrease imports as much as a 1 percent increase in the distance between the importing and exporting countries (Djankov and others, 2010). For exporters, a 10 percent increase in customs delays can reduce foreign sales by nearly 4 percent (Volpe Martincus and others, 2015). While actual achievements will depend on how ambitiously countries put it into practice, various studies have shown that full implementation of the Trade Facilitation Agreement will reduce Members' trade costs by an average of 14 percent-greater than the reduction that would flow from a hypothetical elimination of all remaining tariffs worldwide (WTO, 2015).

45. Remaining market access barriers weigh on global trade. ${ }^{33}$ Remaining tariffs vary greatly across countries and sectors. In G20 advanced economies, applied MFN tariffs average 15 percent in agriculture (see also Section III)—hurting not only poorer countries but also poorer domestic households-and 4 percent for other goods. ${ }^{34}$ For G20 emerging economies, applied tariffs average 16 percent in agriculture and 9 percent for other goods. Important issues remain with the sectoral pattern of tariffs and with gaps between the applied and bound rates of tariffs. ${ }^{35}$ For many members, tariff rates for substantial numbers of non-agricultural products remain unbound in the WTO. The benefits of preferential tariff cuts under regional trade agreements are limited by their scope ${ }^{36}$ and

\footnotetext{
33 Just the elimination of remaining tariff barriers is estimated to permanently increase welfare levels by 0.6 percent in EMDEs and 0.7 percent in AEs, on average (Spearot, 2016).

${ }^{34}$ Besides agriculture, tariffs tend to be high in sectors such as textiles and clothing, and vehicles (UNCTAD, 2015b).

35 A pattern of "tariff escalation" remains more prominent in advanced economies, where rates on finished goods average 9 percentage points above those on raw products (World Bank, 2015). Among emerging market and developing countries, large gaps between applied tariffs (averaging about 10 percent) and WTO ceiling bindings (about 30 percent) create uncertainty about future policy; these gaps reflect that many countries made beneficial unilateral tariff reductions outside the context of WTO negotiations.

${ }^{36}$ Between 2001 and 2013, PTAs reduced average applied tariffs by 0.3 percentage points, whereas WTO scheduled commitments and countries' unilateral liberalization reduced them by 1.1 and 1.3 percentage points, respectively (Bureau and others, 2016).
} 
the requirement that exporters source inputs from suppliers within the region, which can fragment regional and global value chains (Conconi and others, forthcoming); as a result, preference utilization rates are often low (WTO, 2011a). Tariffs are compounded by large non-tariff barriers: quantity- and price-control NTMs affect over 40 percent of imports, including in high-income countries (IMF-WB-WTO, 2017).

\section{Besides tariffs, discrimination in government procurement policies is widespread.}

Participation in agreements that open procurement markets has the potential of not only promoting competition (Evenett and Hoekman, 2004), but also enhancing transparency, and thus reducing corruption (Anderson and others, 2016). Given that in most cases government spending in services outweighs goods purchases, allowing for foreign competition in procurement markets can be particularly effective to promote services growth (Chen and Whalley, 2011).

\section{A market access agenda should reduce tariff and nontariff barriers, promote} transparency, and enhance policy stability. Tariff reductions could usefully target higher tariff rates more, bringing down averages and variation, which are especially high in agriculture; addressing tariff escalation; and closing gaps between bound and applied rates. Longer transitional periods may be appropriate for the smallest and poorest developing countries. Complementary reductions could be pursued by groups of WTO members comprising some critical mass of global trade in particular sectors, as done for information technology (IT) products, with these tariff reductions applied "MFN," that is, on trade with all WTO members. Increased participation of WTO members in the Agreement on Government Procurement could lead to strengthened transparency commitments and more ambitious commitments among both current and new signatories.

\section{Flexible negotiation approaches have yielded results at the multilateral level. As} discussed further in Section IV, the area of market access exemplifies how progress has been achieved not only through large-scale undertakings, such as the Uruguay Round, but also through other varied approaches. These formats have delivered results in diverse areas, from tariff reductions (e.g., the Information Technology Agreement, "ITA"), trade facilitation (the Trade Facilitation Agreement) and government procurement (Agreement on Government Procurement). More information is provided in Section IV. As no single approach necessarily works for all issues, forging a way forward could usefully tap the WTO's adaptable system (WTO, 2016a). WTO agreements are also underpinned by a unique dispute settlement mechanism that has proven far more effective to resolve disputes than any existing PTA mechanism (Davis, 2012 and Vidigal, 2017).

\section{TRADE-RELATED POLICIES FOR INCLUSIVENESS}

\section{A. Trade and the Empowerment of Poor People}

49. Trade can be a powerful force for poverty reduction and inclusive growth. Trade can lower poverty and promote inclusive growth by empowering poor and marginalized groups-the majority of whom, particularly in EMDCs, tend to reside in rural areas; work in the informal sector, 
and are women; this suggests the potential importance of policies in such sectors as farming and light manufacturing (e.g., textiles, clothing). The channels through which trade helps marginalized groups in particular include increasing job opportunities, making goods and services consumed by poor households cheaper, lowering the pecuniary and non-pecuniary barriers to trade that fall most heavily on poorer producers, and facilitating the access to information and technology that can transform production processes or make them more efficient. To deliver these benefits also requires complementary policies that improve infrastructure and networks, simplify trade requirements, improve institutions, and facilitate access to finance.

50. By increasing competition, lowering prices, and raising real incomes, trade can empower the poor and raise their living standards. Poor households spend relatively more on tradeable goods (Cravino and Levchenko, 2017) and the reduction in prices from the competition that trade brings raises their real incomes (Faijgelbaum and Khandelwal, 2016). Furthermore, by increasing the variety of products available to the poor, and lowering the cost of living, poorer segments of society could experience large income and welfare gains (Hausman, 2003). If these gains are invested in health and education, trade will also improve long-run development outcomes.

\section{Trade will be pro-poor if it promotes competition that undermines rents previously} earned by monopolies and cartels. For example, sheltered from international competition by trade barriers, Kenya's sugar market is highly concentrated and, in consequence, the largest players have significant power over prices. Indeed, Kenyan sugar prices remain very high relative to international prices. In this context, the removal of trade barriers would result in a more competitive market that would enable 40,000 families to cross the poverty line, a decline in poverty of 1.5 percent in Kenya (Argent and Begazo, 2015). Small sugar farmers are unlikely to face significant losses because most of the rents that come from the trade barriers are accumulated by the concentrated milling sector.

\section{Policies that lower the pecuniary and non-pecuniary trade barriers in domestic and} overseas markets will benefit the poor. The incidence of non-tariff barriers tends to fall more heavily on poor producers and consumers. For example, Nigeria bans imports of 27 groups of items, which raise domestic prices by as much as 92 percent to the benefit of interests that own domestic production of those items. Eliminating these import bans and replacing them with tariffs at the average level of Nigerian tariffs for comparable goods would raise the real income of Nigerians by an average of 8.5 percent and enable 3.3 million Nigerians to exit poverty (Cadot and others, 2018).

53. Trade barriers in overseas markets that limit access for a country's exports also tend to be regressive, falling most heavily on the poor of that country. In India, for example, tariffs in international markets are higher, and non-tariff measures more numerous, on goods produced by poor workers than on goods produced by rich workers. Tariffs also tend to be higher (i) on goods produced in rural and more remote areas (as compared to tariffs on goods produced in urban centers), (ii) on goods produced by informal enterprises (rather than by formal enterprises), and 
(iii) on goods in which women are more heavily involved in production. The global reduction in tariffs from 1996 to 2012 failed to reduce these differences (Mendoza and others, 2018).

\section{B. Rural Economy}

54. In many countries, extreme poverty and food insecurity is concentrated in rural areas. For example, around 75 per cent of Africa's extreme poor live in rural areas. The rural poor rely largely on agriculture for their livelihoods, and poverty is linked to low agricultural productivitymaking agricultural development critical to poverty reduction.

55. Agricultural and fisheries policies impact market access and food price developments, affecting poor farmers and poor consumers. Distortions to agricultural trade can harm poor producers by reducing their prices and eroding their competitiveness. Farm subsidies, particularly in large economies, can depress global prices for farm products, harming farmers in poor countries and hindering their entry into export markets. Export restrictions can segment local markets and make world market prices more volatile; poor producers and poor consumers often lack the tools or resources needed to manage this volatility effectively. Limiting fisheries subsidies can improve livelihoods of those in poor coastal communities and bring more sustainability to fishing (Box 6).

56. Developing country farmers face many challenges in accessing foreign markets. Lower trade barriers can lead to increased sales; however, the benefits can be hampered by poor access to markets and the costs of compliance with standards, particularly those in high-income destination markets. Small holders face particular challenges, especially when located in remote areas in complying with public and private standards for agricultural and food products. Poor access to safe water, reliable electricity, knowledge, and reliable testing services make meeting (and proving compliance with) such standards particularly challenging. Remoteness and weak infrastructure contribute to low producer prices for small farmers and reduce the incentive to produce for the market. Small farmers dispersed across rural areas are unable to benefit from consolidation and scale in selling their output, and often have no choice but to sell to middlemen/intermediaries and as a result, small farmers tend to receive a relatively low price compared to the final price.

57. Even in rural areas where most households are net food consumers, higher food prices can be associated with reduced poverty. Simple simulation models have suggested that since most poor households are net consumers of food, higher food prices are likely to increase poverty in the short run. There are a number of problems with this approach. ${ }^{37}$ Households adjust to higher food prices by increasing productivity and output (e.g., through fertilizers and higher-yielding seeds). They may also allocate more time to activities that generate higher wage income for the household as demand for unskilled labour in rural areas increases. Headey (2016) examines the cross-country evidence from over 50 developing countries and finds that rising food prices are associated with reduced national poverty rates. This is driven by (i) the large number of poor people

\footnotetext{
${ }^{37}$ There are issues over the reliability of the data on the net food position of households from household surveys. Large errors may result from recall biases that result in the underestimation of food production and from annualization of short recall responses that overstate consumption (Headey, 2016).
} 
who still live in rural areas, with their welfare largely determined by farm and non-farm agricultural incomes (ii) the rapid increase in agricultural supply in many countries in response to higher prices and (iii) in some cases, the relatively faster increase in rural wages as compared to urban wages. However, domestic price support measures in developing countries can also contribute to undernourishment within poorer households and have a negative impact on poverty; policies targeted toward the most vulnerable segments of the population could avoid this.

\section{Box 6. Fisheries Subsidies Negotiations at the WTO}

Since 2001, WTO members have been engaged in negotiations to discipline subsidies to the fisheries sector that contribute to overcapacity and overfishing, including subsidies to illegal, unreported and unregulated (IUU) fishing. These negotiations could bring about a "triple win" for trade, development and the environment by reducing the trade-distortive effects of such subsidies in ways that promote economic development. The sustainability of fish stocks could be protected, inter alia by redirecting public funds away from payments that encourage production and toward better fisheries management, allowing the sector to regain profitability.

While much of debate in the negotiations is focused on subsidies to industrial fisheries, including those on the high seas, the role of subsidies in the artisanal and small-scale fisheries in developing country Members also occupies an important role in the negotiations. Negotiators are seeking a balance between governments' provision of support to poor and vulnerable communities where fisheries is a major source of jobs, nutrition and income, against governments' responsibility to husband the fisheries resources for future generations, including by avoiding support of unsustainable levels of fishing.

The 2017 WTO Ministerial Decision on Fisheries Subsidies mirrors the language of SDG Target 14.6 and reflects these different priorities. It targets completion of negotiations by the 12th WTO Ministerial Conference in 2019, and calls for comprehensive disciplines to prohibit subsidies to IUU fishing and other subsidies that contribute to overcapacity and overfishing, with special provisions for developing country and LDC Members.

\section{Micro, Small, and Medium-Sized Enterprises}

\section{Micro, small, and medium-sized enterprises (MSMEs) play an essential role in promoting inclusiveness, but participation in trade remains limited. ${ }^{38}$ MSMEs represent more} than 90 percent of registered companies and account for around two-thirds of total employment in both developed and developing countries. Calculations based on the World Bank Enterprise Survey indicate that direct exports by MSMEs amount to only 7.6 percent of total MSME sales in the manufacturing sector, compared to 14.1 percent for large manufacturing enterprises. The relatively low level of MSME trade has been ascribed to various barriers, such as access to information, access to trade finance, non-tariff barriers (NTBs), cumbersome regulations and border procedures, and poor physical and ICT infrastructure. ${ }^{39}$ Increasing de minimis thresholds so that tariffs are not assessed on small-value shipments (Section II.C) can promote MSMEs' participation in e-commerce.

\footnotetext{
38 Although no single MSME definition exists, they are generally considered to be firms of less than 250 employees.

39 According to a 2015 ITC Monitoring Survey, the largest problems faced by MSMEs when exporting were "access to information about export opportunities," "access to information on procedures and regulations in order to export or import," and "access to trade finance". Over half of SMEs' trade finance requests are rejected, compared to 7 percent of requests by large firms (WTO, 2016b). Tax and regulatory compliance costs may also disproportionately affect MSMEs (OECD, 2017), hindering their participation in trade.
} 
59. E-commerce is increasing the ability of MSMEs to grow by exporting, underlining the importance of building a stronger global framework around e-commerce. By lowering trade costs, e-commerce can promote inclusion for small firms, which are least able to overcome the initial costs of participating in trade. Export survival rates appear to be much higher for firms involved in e-commerce (Meltzer, 2016) and e-commerce has been shown to facilitate the participation of small firms in trade, in part because it allows MSMEs to reach customers at lower costs. According to AliResearch (2017), more than 95 percent of companies using the Alibaba platform have fewer than 5 employees. On average, 97 per cent of internet-enabled small businesses export (WTO, 2016b). Further, e-commerce provides a space for sales by those discriminated against in traditional distribution networks, such as women. In fact, certain platforms, such as Etsy, have been shown to be predominantly women-owned MSMEs.

60. Improved trade policies could help to enhance MSME participation in trade. The special situation of MSMEs is addressed in a number of regional trade agreements (Monteiro, 2016), as well as in some WTO agreements and work programs. Most recently, 88 WTO Members have established an Informal Working Group to look into how trade challenges faced by MSMEs could be addressed at the WTO. Issues under discussion include how access to information and access to trade finance could be enhanced, and how border procedures could be further facilitated.

\section{Gender}

61. Trade helps to drive female employment. Trade generates jobs for women, including through employment in the formal sector among those previously employed in the informal sector. MSMEs account for 52 percent of employment in developing economies (ILO, 2017) and employ women disproportionately (WTO, 2017). Exports now represent just 8 percent of total sales of developing country MSME manufacturers, but raising MSME participation in trade seems likely to promote female employment (WTO, 2016b). In a recent study of Indonesia, Kis-Katos and others (2018) find that reduced import tariffs on locally-relevant inputs led to greater work participation, more work hours, and reduced domestic duties by women, especially those less-educated, with no similar effects for men.

\section{Exporters in developing countries employ more women than non-exporters and jobs} in export sectors tend to have better pay and conditions than those in the informal sector. In many developing economies women comprise up to 90 percent of the workforce in export processing zones, bringing jobs that provide higher income and greater job stability (World Bank and WTO, 2015). The growth of global and regional supply chain trade, such as in apparel and assembled goods, has been a strong source of employment for women in developing countries.

\section{Many governments are now acting to support the participation of women in trade.}

The Buenos Aires Declaration on Trade and Women's Economic Empowerment, signed by 121 WTO Members and Observers representing three-quarters of global trade, seeks to ensure that the WTO works to make trade more inclusive and increases the participation of women in trade. 
64. The impact of trade and trade policy on women is complex. Women can be affected by trade as consumers, as producers of traded goods and services, and as entrepreneurs with dominant ownership of exporting companies. The trade impact on female producers or exporters also depends on the role in the economy of the sector or industry where they are specializing and on whether they are employed in large or small firms. While the export sector is an important source of employment for women, the services sector is the largest employer of women. Further services trade reform, coupled with domestic regulatory reform, could thus help to drive further job creation for women in service sectors such as health, finance, and tourism, and in areas such as communications, distribution, and logistics that are becoming increasingly tradable.

\section{In many countries, women are constrained from fully participating in or benefiting}

from trade. Specific constraints include access to credit, land and other resources, asymmetric household responsibilities, gendered social norms, labor market segregation and lower skills and lack of training. Women are often heavily involved in cross-border trade-in the Great Lakes region of Africa, about three-quarters of small-scale cross-border traders are women-but are less likely than men to be aware of their rights and of legal conditions governing trade at the border. In a 2010 survey of those traders, more than 80 percent reported having to pay bribes to cross the border (Brenton and others, 2012), while more than half had suffered physical harassment and abuse.

66. Farming often presents specific issues. In many poor countries, seeds, fertilizers and pesticides are predominantly imported; however, women often find it more difficult to interact with markets as they are bypassed by traditional male-dominated distribution networks, are less likely to receive technical information, and farm support programs may exclude crops grown primarily by women..$^{40}$ Improved access to markets for women farmers would increase use of modern inputs and enable them to sell more of what they produce-helping to close the gender productivity gap in agriculture, raising agricultural output, and improving the welfare of households of female farmers.

\section{Through its impact on job creation, trade can enhance the status of women in society and empower women within the household. Employment of women has been shown to have} positive long-term development outcomes through the greater influence of women on household decisions on education, food, and health expenditures, and on the status of girls. ${ }^{41}$ Decisions that improve the caloric intake of children and reduce stunting improve educational attainment and adult productivity. By creating jobs for women, trade can also increase incentives for girls to attend school and training (Jensen, 2012; Heath and Mobarak, 2015), and greater job opportunities through trade bring an increased focus and expenditure on education for all children in the household (Oster and Steinberg, 2013). Finally, job creation through trade can empower women in social and political

\footnotetext{
${ }^{40}$ Larson and others (2015) find that in Uganda, after controlling for these factors, observed productivity differences between female and male farmers disappear.

41 Hyder (2016) notes that "as garments workers, women are now earning salaries, participating in formal sector work, managing personal finances, encouraging their children to pursue higher education, and defying traditional marriage standards by marrying later. The garments industry has created the rise of financially independent and successful women in Bangladesh and is responsible for a dramatic shift in paradigm for Bangladeshi society."
} 
spheres, making institutions more representative and changing policies that lead to increases in the provision of public goods (education, health, sanitation, water) which contribute to long-term development (Beaman and others, 2011).

\section{E. Complementary Policies to Support Inclusiveness}

68. Policies can help to ease adjustment and ensure inclusiveness. While trade enlarges the economic pie, it sometimes, along with technological progress and other structural changes, imposes adjustment costs on groups of workers and some communities, triggering discontent among some segments of society. Policies to facilitate that adjustment will help to share the gains from trade more widely. Building on the comprehensive typology of alternative adjustment policies developed in Section V of IMF-WB-WTO (2017), this section updates the evidence on the design and effectiveness of adjustment policies. Since technological progress is also associated with gains and losses that are unevenly distributed, these policies are equally relevant when coping with adjustment due to technological improvements.

\section{Better understanding the full response to "trade shocks" can provide greater insights} on the focus of adjustment policies. While import competition can displace workers from certain sectors or locations, the aggregate employment effects of increased import competition tend to be neutral to positive, leading to better jobs overall. The work of Autor and others $(2013,2016)$ concluded that U.S. localities more exposed to Chinese manufacturing import competition experienced larger declines in employment and earnings. However, that work did not consider the offsetting roles of exports and supply chains. Feenstra and others (2017) conclude that job gains related to increased exports largely offset the job losses due to China's import penetration. ${ }^{42}$ Similarly, evidence from Germany associates increased import competition from China and Central and Eastern Europe with greater export growth and net job creation (Dauth and others, 2015). Policies should aim to enhance the ability of workers to move to expanding sectors.

\section{Drawing also on the more recent evidence suggests a few broad principles for the design of complementary policies.}

- Improving the ability of workers to move across industries, regions, and skills is key. Important social safety nets such as unemployment insurance can provide workers with the chance to retool and policymakers with the time to deploy more targeted policies. Policies toward housing, credit, and education can promote mobility.

- Well-designed adjustment programs can help. Evidence on the overall effectiveness of trade adjustment assistance programs remains mixed (IMF/WB/WTO, 2017). ${ }^{43}$ Assistance for displaced workers should be economy-wide, and not necessarily focused on trade-related displacement (Kletzer and Litan, 2001). Wage insurance, subsidies for health insurance for

\footnotetext{
42 Similarly, they are also found to fully offset the job losses due to imports from all countries, when the services sector is included (Feenstra and Sasahara, 2017).

43 However, the vocational skills acquired from TAA training became obsolete over time, with returns fully depreciating in ten years.
} 
displaced workers, and support for vocational training and formal education may all play a role.

- In severe instances, policy responses should be prompt and targeted, and place-based policies should be considered. Abrupt increases in import competition can have concentrated effects on certain industries and communities and lead to long-term nonemployment, with social and economic hardships. In some cases, prompt action with targeted place-based policies can help. Austin and others (2018) suggest that employmentfocused programs tailored to local circumstances improve outcomes. ${ }^{44}$

71. In developing and emerging economies, factors such as the extent of labor market informality need to be considered. Workers displaced after Brazil's trade liberalization in the early 1990s spent considerable time in non-employment before eventually switching to the informal sector, typically with lower-quality jobs; this highlights the role of the informal sector in absorbing trade-related displacements (Dix-Carneiro and Kovak, 2017a). Informal sector earnings were not affected by trade liberalization, in contrast with the formal sector earnings that declined (Dix-Carneiro and Kovak, 2017b). A finding that workers in tradeable and nontradable sectors incurred similar losses suggests putting in place broad-based policies. Trade-specific adjustment programs on their own may be insufficient, as they compensate only import-competing sectors and do not address those who may be equally impacted through indirect effects.

\section{ROLE OF THE INTERNATIONAL TRADING SYSTEM}

\section{Multilateral trade cooperation is increasingly important in today's hyper-integrated,} multipolar global economy. Many key trade issues, such as e-commerce, are largely global in nature and can only be tackled globally in the WTO. Yet one of the WTO's core strengths-its global scope and membership_also makes it more challenging to advance and 'upgrade.' The last major reform of the system, the Uruguay Round, was concluded almost a quarter century ago and addressed the agenda of the 1980s. The WTO Agreement does not tie negotiators to predetermined negotiating approaches, but allows for a variety of approaches. The urgent challenge today is to harness the unique strength of the WTO-an institutional, legal, and enforcement character that cannot be matched in bilateral and regional trade agreements-to tackle the key trade issues of today, using the most effective approaches available.

73. In these times of fast-moving change in the global economy there is a need now more than ever to ensure that the rules, policies, and practices governing global trade evolve and are modernized. Since its creation immediately after the Second World War, the system has evolved and adapted in response to new economic activities, new trade participants, and new 'integrating' technologies. Although this evolution has not always been smooth-often advancing in fits and starts-two long-term trends are striking.

\footnotetext{
44 Research such as Case and Deaton (2017) and Krueger (2017) associate social and health problems more with employment rather than income.
} 
- First, multilateral trade cooperation has grown wider and deeper with more countries, more issues, and more rules being consolidated in the increasingly global architecture. Launched as a limited tariff agreement among 23 members, the 1947 GATT grew into the modern WTO, with multi-issue economic agreements among 164 members. International trade relations have in turn become increasingly open, integrated, and interdependentfurther reinforcing the logic of global cooperation and rules.

- Second, WTO negotiations have included all members, but members have had varied ambitions and undertaken varied commitments, especially as the system has grown more diverse. Every negotiation has been multi-speed, with some members going further and faster than others. The resulting agreements have been 'variable geometry,' with outcomes that accommodated different obligations on issues such as tariff schedules and services commitments, anchored in common principles and general rules.

74. The practice of bundling negotiating issues together in giant, all-or-nothing trade rounds has become extremely difficult to manage. This "single undertaking" approach-where every country has a stake and say in the outcome and "nothing is agreed until everything is agreed"-delivered, in the Uruguay Round, a large, far-reaching package across a wide range of issues and sectors. Yet it became increasingly vulnerable to delays and deadlocks as progress on more feasible issues was held back by a lack of progress on more controversial and intractable ones. As long as everyone needed to reach agreement, anyone could delay an overall package. The Kennedy Round (1964-67) took almost four years to complete; the Tokyo Round (1973-79) six years; and the Uruguay Round (1986-94) over eight years. Meanwhile, the Doha Round, launched in 2001, has already lasted seventeen years with no conclusion in sight. ${ }^{45}$

\section{The slower pace of multilateral negotiations has encouraged countries to turn to} bilateral and regional strategies. This has had positive aspects, but also presents a risk of complicating or fragmenting the trading system. These efforts have been motivated, in part, by a sense that smaller like-minded groups could address the complex challenges of deeper integration easier and more quickly than the broader WTO. The number of RTAs in force and notified to the WTO increased from about 54 in 1995 to over 250 today, yet less than half of global merchandise trade takes place between countries that share an RTA (Figure 5). The most ambitious RTAs go beyond liberalizing trade in goods and services to address deeper integration by devising common regulations and standards governing goods, services, investment, and public procurement markets. ${ }^{46}$

\section{Regional trade agreements can help to advance trade integration, but are not enough} on their own. The more ambitious regional agreements have helped to demonstrate the potential of further integration in new areas. While the growth of more, broader and deeper RTAs clearly demonstrates countries' desire to expand and strengthen international trade cooperation, even the

\footnotetext{
45 Early GATT rounds focused on tariff cutting and proceeded more rapidly. These were the Geneva Round (1947), Annecy Round (1949), Torquay Round (1950-51); Geneva Round (1956); and Dillon Round (1960-61).

${ }^{46}$ Some 66 percent of notified RTAs have provisions on trade in services; 51 percent have provisions on investment liberalization; 74 percent on intellectual property rights; and 71 percent on competition policy. They have taken on average 2.5 years to complete.
} 
most far-reaching mega-regional deals cannot address all modern trade challenges. Because RTAs by definition have limited membership and coverage, their ability to address the policy coordination challenges posed by increasingly 'borderless' global issues like services, investment, or e-commerce is also limited. In addition, proliferating RTAs can create overlapping, inconsistent and fragmented trade regimes-'spaghetti bowl' effects—raising transaction costs and complicating sourcing for businesses that operate in global markets. By design, RTAs are also preferential and exclusionary, with tariff and some other discriminatory provisions potentially trade-diverting.

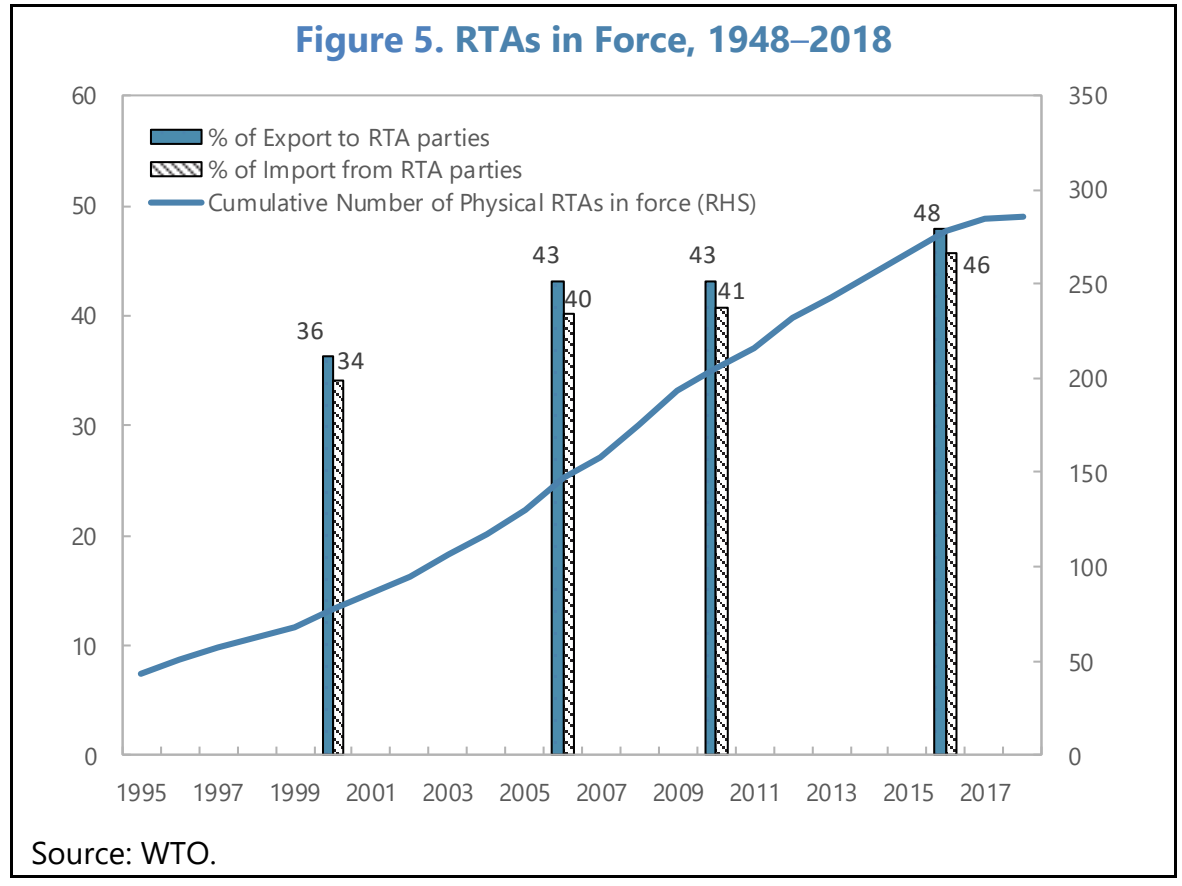

77. These shortcomings are amplified by the fact RTAs tend to define or 'lock-in' trade partnerships by region, while key trade relationships today often transcend geography and are specific to issues or industries, rather than regions. The complex China-EU-US relationship, to take an obvious example, cannot helpfully or even feasibly be addressed by multiple RTAs, regardless of how comprehensive or well-designed. As the only global trade system, the WTO provides the only forum where all countries, including the most powerful, can cooperate on the growing number of global trade issues that impact them collectively. In today's increasingly open, integrated, and multipolar global economy, there is no obvious alternative to the global system of trade rules, policy coordination, and institutional support-especially regarding transparency and dispute settlement-that the WTO now provides.

\section{A more flexible multilateral trading system}

78. As multilateralism becomes more relevant to global trade relations there are signs of it becoming increasingly flexible and multispeed. Several traditional approaches are already being revisited in the context of recent WTO negotiations. 
79. The first is the idea that trade opening and rule-making can only be organized and advanced in ever-bigger multi-issue, multi-year rounds. Recent breakthroughs at the WTO's Bali Ministerial Conference in 2013 and again at the Nairobi Ministerial Conference in 2015 involved smaller negotiated "packages" of issues—where the trade-offs being sought were narrower, where a convergence of interests was possible, and where members had a shared stake in reaching agreement. Bali delivered the Trade Facilitation Agreement-which had eluded negotiators over the course of the Doha Round-while Nairobi produced an agreement to ban agricultural export subsidies and provide new disciplines with respect to international food aid, export finance and agricultural exporting state-trading enterprises aimed at addressing the potential risk to circumvent the ban (Box 7). Interestingly, the notion that multilateral negotiations should move towards continuous, technical level dialogues - and away from giant, make-or-break events-was a key justification for creating a more permanent global trade institution in 1995, the WTO.

80. A second traditional approach being revisited is the idea that all WTO Members canor should-be required to take part in all WTO negotiations. When achievable, multilateral agreements are the optimal way to liberalize world trade and secure global rules. But in certain areas-especially those emerging issues where policy innovation is needed and where not all 164 WTO members are equipped or ready to engage-some countries wish to move further and faster than others, and are doing so. As former WTO Appellate Body Chair James Bacchus (2018) noted, "WTO members have chosen to pursue new trade obligations multilaterally, but they are not required to do so." 47

\section{Several initiatives that are underway could lead to plurilateral agreements. An} important development at the 2017 WTO Ministerial Conference in Buenos Aires was the decision by some WTO members to launch 'open-plurilateral' discussions on e-commerce, investment facilitation, services domestic regulation, and micro, small, and medium-sized enterprises (MSMEs). ${ }^{48}$ In e-commerce and services domestic regulation, this represents an innovation following many years of WTO discussions. Since their objective is seemingly not to exchange market access 'concessions' but to improve regulatory coordination-in order to minimize policy frictions and advance shared goals in a "least trade restrictive" way-they could lead to a more cooperative, less mercantilist, approach to WTO negotiations in the future. Indeed, new rules in these areas would likely be inherently non-discriminatory-because they involve domestic regulations that cannot easily be tailored to benefit specific trade partners—-making concerns about "discrimination," like calculations of "reciprocity," less relevant. ${ }^{49}$

\footnotetext{
${ }^{47}$ He continues: "An option provided by the WTO treaty is to pursue new trade obligations plurilaterally through negotiations among a self-selected subset of WTO members seeking the perceived economic advantages of agreements within the WTO rules framework...."

48 Bertelsmann Stiftung (2018) summarizes some of these discussions.

${ }^{49}$ Hoekman and Mavroidis (2015) discuss the WTO institutional framework as it relates to alternative negotiating approaches such as plurilateral agreements.
} 
Box 7. GATT/WTO: Selected Experience with Alternative Negotiating Approaches

Although GATT/WTO negotiations have come to be associated with large-scale "single undertakings" such as the Uruguay Round outcome and the Doha Round agenda, the WTO Agreement allows for various approaches. Indeed, great progress has been made through other approaches, before the Uruguay Round and since.

Several plurilateral "codes" from the Tokyo Round later became full multilateral agreements. A subset of GATT members agreed on additional rules in several areas, including customs valuation, subsidies, and technical barriers to trade. These "codes" were binding among the signatories and subject to GATT dispute settlement. With the conclusion of the Uruguay Round, these agreements became multilateral-binding on and enforceable by all WTO members.

The Agreement on Government Procurement (AGP) began as, and remains, a plurilateral agreement. The AGP was also introduced in the Uruguay Round. The obligations of participants extend only to other participants (and not to non-participating WTO members). It is open to new participants and to further negotiation to improve existing commitments.

"Critical mass" agreements are negotiated by a subset of WTO members, with benefits extended to all members. The expanded Information Technology Agreement (ITA; 2015) commits its 53 participants (accounting for 90 percent of world trade in the covered products) to eliminate all tariffs (on an MFN basis) on a further 201 products. Similarly, commitments made in 1997 by around 70 WTO members as a result of extended negotiations on Basic Telecommunications and Financial Services are applied on an MFN basis to all WTO members.

The WTO Trade Facilitation Agreement (2013) is a fully multilateral agreement that was unbundled from a broader initiative. The topic of trade facilitation is part of the Doha Development Agenda agreed in 2001. Recognizing the benefits of a cooperative approach to strengthening customs practices, however, WTO members decided to conclude the TFA separately rather than to wait for conclusion of an overall Doha Round. The TFA is binding on and enforceable by all WTO members; it uses innovative approaches to allow for multi-speed implementation by developing countries and LDCs, and provides for implementation assistance.

Ministerial decisions can also be used. For example, WTO members agreed in 2013 to eliminate farm export subsidies.

82. The WTO can adapt and deliver results when its members work together. In 2013, WTO Members negotiated the Trade Facilitation Agreement; in 2015, they concluded the Information Technology Agreement expansion deal and the agreement to ban all forms of agricultural export subsidies; and in 2017, many joined in launching discussions on key $21^{\text {st }}$ century trade issues like e-commerce and investment facilitation. Although some are not currently in a position to support them, these initiatives remain open for any WTO member to join. In each case, negotiating success resulted from combining continuity and reform. Today's fast-changing global trade landscape clearly requires a parallel change in global trade governance if multilateral trade liberalization is to remain an engine of inclusive global growth. In the end, the WTO represents no more or less than the willingness of its members to cooperate-and to recognize that their national economic interests are increasingly bound up with their collective economic interests. The system is a resultas much as a cause - of their commitment to deepening their economic integration and interdependence. Whether the system continues to evolve, adapt and succeed is up to them. 


\section{References}

Adlung, R. 2015. "The Trade in Services Agreement and its Compatibility with the GATS: An Assessment Based on Current Evidence." World Trade Review.

Adlung, R. and H. Mamdouh. 2018. "Plurilateral Trade Agreements: An Escape Route for the WTO?" Journal of World Trade.

Ahn, J., E. Dabla-Norris, R. Duval, B. Hu, and L. Njie, 2016. "Reassessing the Productivity Gains from Trade Liberalization." International Monetary Fund, Working Paper 16/77.

AliResearch. 2017. "Inclusive Growth and E-Commerce: China's Experience." Prepared for a meeting on Inclusive Development and E-Commerce: The Case of China, UNCTAD, April 2017.

Anderson, R., W. Kovacic, and A. Muelller. 2016. "Promoting Competition and Deterring Corruption in Public Procurement Markets: Synergies with Trade Liberalisation." E15 Expert Group on Competition Policy and the Trade System.

Argent, J. and T. Begazo. 2015. "Competition in Kenyan Markets and its Impact on Income and Poverty: A Case Study on Sugar and Maize." World Bank Policy Research Working Paper, 7179.

Arnold, J., B. Javorcik, M. Lipscomb and A. Mattoo. 2016. "Services Reform and Manufacturing Performance: Evidence from India." Economic Journal.

Asian Development Bank (ADB). 2013. "Trade and Procurement: Effective Public Purchasing and Market Access." Manila, Philippines.

Austin, B., E. Glaeser, and L. Summers. 2018. "Saving the Heartland: Place-Based Policies in $21^{\text {st }}$ Century America." Brookings Papers on Economic Activity, BPEA Conference Drafts, March.

Autor, D., D. Dorn and G. Hanson. 2013. "The China Syndrome: Local Labor Market Effects of Import Competition in the United States." American Economic Review.

Autor, D., D. Dorn and G. Hanson. 2016. "The China Shocks: Learning from Labor Market Adjustment to Large Changes in Trade." Annual Review of Economics.

Bacchus, J. 2018. "Was Buenos Aires the Beginning of the End or the End of the Beginning? The Future of the World Trade Organization." Cato Institute Policy Analysis No. 841.

BEA (U.S. Bureau of Economic Analysis). 2018. "Defining and Measuring the Digital Economy." BEA Working Paper.

Beaman, L., R. Chattopadhya, E. Duflo, R. Pande, and P. Topalova. 2011. "Political Reservation and Substantive Representation: Evidence from Indian Village Councils." In S. Bery, B. Bosworth, and A. Panagariya_eds.) India Policy Forum 2010-11. Brookings Institution and NCAER.

Bertelsmann Stiftung. 2018. "Revitalizing Multilateral Governance at the World Trade Organization."

Beverelli, C., M. Fiorini, and B. Hoekman. 2017. "Services Trade Policy and Manufacturing Productivity: The Role of Institutions." Journal of International Economics.

Borchert, I., B. Gootiiz, and A. Mattoo. 2011. "Services in Doha: What's on the Table?" In W. Martin and A. Mattoo (eds.), Unfinished Business? The WTO's Doha Agenda. CEPR and World Bank.

Brenton. P., C. Bashinge Bucekuderhwa, C. Hossein, S. Nagaki and J.B. Ntagoma. 2012. "Risky Business: Poor Women Cross-border Traders in the Great Lakes Region of Africa." In P. Brenton, and G. Isik (eds.) De-Fragmenting Africa: Deepening Regional Trade Integration in Goods and Services. World Bank.

Bureau, J.-C., Houssein G., and S. Jean. 2016. "Competing Liberalizations: Tariffs and Trade in the $21^{\text {st }}$ Century." CEPII Working Paper No. 2016-12. 
Bustos, P. 2011. "Trade Liberalization, Exports, and Technology Upgrading: Evidence on the Impact of MERCOSUR on Argentinian Firms." American Economic Review.

Cadestin, C., K. De Backer, I. Desnoyers-James, S. Miroudot, M. Ye, and D. Rigo. 2018. "Multinational Enterprises and Global Value Chains: New Insights on the Trade-investment Nexus." OECD Science, Technology and Industry Working Papers, 2018/05.

Cadot, O., M. Ferrantino, J. Gourdon and D. Reyes. 2018. "Reforming Non-Tariff Measures: From Evidence To Policy Advice." World Bank.

Case, A. and A. Deaton. 2017. "Mortality and Morbidity in the $21^{\text {st }}$ Century." Brookings Papers on Economic Activity, Spring.

Cerdeiro, D. and R. Nam. 2018. "A Multidimensional Approach to Trade Policy Indicators." IMF WP 18/32.

Chen, H. and J. Whalley. 2011. "The WTO Government Procurement Agreement and Its Impacts on Trade." NBER WP 17365.

Cline, W. 2010. "Financial Globalization, Economic Growth, and the Crisis of 2007-09." Peterson Institute for International Economics.

Conconi, P., M. Garcia-Santana, L. Puccio, and R. Venturini. Forthcoming. "From Final Goods to Inputs: The Protectionist Effect of Rules of Origin." American Economic Review.

Cravino, J. and A. Levchenko. 2017. "The Distributional Consequences of Large Devaluations." American Economic Review.

Crosby, D. 2016. "Analysis of Data Localization Measures Under WTO Services Trade Rules and Commitments." E15 Initiative. Geneva: International Centre for Trade and Sustainable Development (ICTSD) and World Economic Forum, 2016.

Dauth, W., S. Findeisen, and J. Suedekum. 2015. "Trade and Manufacturing Jobs in Germany." American Economic Review.

Davis, C. 2012. Why Adjudicate? Enforcing Trade Rules in the WTO. Princeton University Press.

Dix-Carneiro, R. and B. Kovak. 2017a, "Margins of Labor Market Adjustment to Trade." NBER WP 23595.

Dix-Carneiro, R. and B. Kovak. 2017b, "Trade Liberalizations and Regional Dynamics." American Economic Review.

Djankov, S., C. Freund, and C. Pham. 2010. "Trading on Time." Review of Economics and Statistics.

Evenett, S. and B. Hoekman. 2004. "International Disciplines in Government Procurement: A Review of Economic Analyses and their Implications." Mimeo.

Faijgelbaum, P. and A. Khandelwal. 2016. "Measuring the Unequal Gains from Trade." The Quarterly Journal of Economics.

Falk, M. and E. Hagsten. 2015. "E-commerce Trends and Impacts across Europe." UNCTAD Discussion Paper 220.

Feenstra, R., H. Ma and Y. Xu. 2017. "US Exports and Employment." NBER WP 24056.

Feenstra, R. and A. Sasahara. 2017. "The 'China Shock', Exports, and US Employment: A Global InputOutput Analysis." NBER WP 24022.

Fiorini, M. and B. Hoekman. 2017. "Services Trade Policy and Sustainable Development." European University Institute, Robert Schuman Centre for Advanced Studies, Working Paper 2017/41.

Freund, C. and D. Weinhold. 2004. "The Effect of the Internet on International Trade." Journal of International Economics. 
Freund, C. and D. Weinhold. 2002. "The Internet and International Trade in Services." American Economic Review.

Goldberg, P., A. Khandelwal, N. Pavcnik, and P. Topalova. 2010. "Imported Intermediate Inputs and Domestic Product Growth: Evidence from India," The Quarterly Journal of Economics.

Gonzalez, A. 2013. "Executive Summary" in "FDI as a Key Driver for Trade, Growth and Prosperity: The Case for a Multilateral Agreement on Investment." World Economic Forum Global Agenda Council on Global Trade and FDI.

Gootiiz, B. and A. Mattoo. 2017. "Services in the Trans-Pacific Partnership: What would be Lost?" World Bank Policy Research Working Paper No. 7964.

Handley, K. 2014. "Exporting under Trade Policy Uncertainty: Theory and Evidence." Journal of International Economics.

Headey, D. 2016. "Food Prices and Poverty." World Bank Policy Research WP 7898.

Heath, R. and A. Mobarak. 2015. "Manufacturing Growth and the Lives of Bangladeshi Women." Journal of Development Economics.

Hoekman, B. and A. Mattoo. 2008. "Services Trade and Growth." In J. Marchetti and M. Roy (eds.), Opening Markets for Trade in Services. Cambridge University Press.

Hoekman, B. and P. Mavroidis. 2015. "WTO 'a la Carte' or 'Menu du Jour'? Assessing the Case for More Plurilateral Agreements." European Journal of International Law.

Hufbauer, G. and P. Draper. 2016. "FDI as a Key Driver for Trade, Growth and Prosperity: Facts and Figures."

Hufbauer, G., B. Jensen, and S. Stephenson. 2012. "Policy Brief: Framework for the International Services Agreement." Peterson Institute for International Economics.

Hyder, S. 2016. "Women's Financial Independence Amongst Female Garments Workers in Bangladesh: Summary of Research." Mimeo, School of Law, University of California.

Hyman, B., 2018. "Can Displaced Labor be Retrained? Evidence from Quasi-Random Assignment to Trade Adjustment Assistance." The Wharton School, University of Pennsylvania.

International Federation of Accountants and Business at OECD. 2018. "Regulatory Divergence: Costs, Risks, Impacts."

International Finance Corporation. 2011. "Strengthening Access to Finance for Women-Owned SMEs in Developing Countries."

ILO (International Labour Organization). 2017. World Employment and Social Outlook 2017: Sustainable Enterprises and Jobs_Formal Enterprises and Decent Work. Geneva.

IMF. 2018a. "Is Productivity Growth Shared in a Globalized Economy?" World Economic Outlook Chapter 4, April. International Monetary Fund.

IMF. 2018b. "Manufacturing Jobs: Implications for Productivity and Inequality." World Economic Outlook Chapter 3, April. International Monetary Fund.

IMF. 2016a. "Global Trade: What is Behind the Slowdown?" World Economic Outlook, October. International Monetary Fund.

IMF. 2016b. "Reinvigorating Trade to Support Growth: A Path Forward," Prepared for the July 2016 Meeting of G-20 Finance Ministers and Central Bank Governors by staff of the International Monetary Fund. 
IMF, WB, and WTO. 2017. "Making Trade an Engine of Growth for All: The Case for Trade and for Policies to Facilitate Adjustment." Prepared for discussion at the March 2017 meeting of G20 Sherpas by staffs of the International Monetary Fund, World Bank, and World Trade Organization.

International Trade Centre (ITC). 2015. "How Companies Experience Non-tariff Measures: Survey-based Evidence from Developing Countries." ITC Technical Paper.

Jensen, R. 2012. "Do Labor Market Opportunities Affect Young Women's Work and Family Decisions? Experimental Evidence from India." Quarterly Journal of Economics.

Johnson, R. 2014. "Five Facts about Value-Added Exports and Implications for Macroeconomics and Trade Research." Journal of Economic Perspectives.

Johnson, R. and G. Noguera. 2017. "A Portrait of Trade in Value-Added over Four Decades." Review of Economics and Statistics.

Kis-Katos, K., J. Pieters, and R. Sparrow. 2018. "Globalization and Social Change: Gender-Specific Effects of Trade Liberalization in Indonesia." IMF Economic Review.

Kletzer, L. and R. Litan. 2001. "A Prescription to Relieve Worker Anxiety." Policy Briefs PB01-02, Peterson Institute for International Economics

Kommerskollegium. 2015. Online Trade, Offline Rules A Review of Barriers to E-commerce in the EU. National Board of Trade, May 2015.

Koske, I., I. Wanner, R. Bitetti, and O. Barbiero. 2015. "The 2013 Update of the OECD's Database on Product Market Regulation: Policy Insights for OECD and non-OECD Countries." OECD WP No. 1200.

Kox, H. and A. Lejour. 2005. "Regulatory Heterogeneity as Obstacle for International Services Trade," CPB Discussion Paper 49, CPB Netherlands Bureau for Economic Policy Analysis.

Krueger, A. 2017. "Where Have All the Workers Gone? An Inquiry into the Decline in the U.S. Labor Force Participation Rate." Brookings Papers on Economic Activity, Fall.

Larson, D., S. Savastano, S. Murray and A. Palacios-Lopez. 2015.. "Are Women less Productive Farmers? How Markets and Risk Affect Fertilizer Use, Productivity, and Measured Gender Effects in Uganda." World Bank, Policy Research Working Paper.

López-González, J. and M. Jouanjean. 2017. "Digital Trade: Developing a Framework for Analysis." OECD Trade Policy Papers No. 205.

Low, P. 2016. "Rethinking Services in a Changing World." Policy Options Paper for the E15 Initiative; International Center for Trade and Sustainable Development and World Economic Forum.

Mattoo, A. and J. Meltzer. 2018. "International Data Flows and Privacy: The Conflict and Its Resolution." World Bank Policy Research Working Paper No. 8431.

Mattoo, A., and P. Sauve (eds.). 2003. Domestic Regulation and Services Trade Liberalization. Oxford University Press and World Bank.

Mavroidis, P. 2016. "Regulatory Cooperation: Lessons from the WTO and the World Trade Regime." Policy Options Paper for the E15 Initiative, ICTSD and World Economic Forum.

Meltzer, J. 2016. "Maximizing the Opportunities of the Internet for International Trade." Policy Options Paper for the E15 Initiative, ICTSD and World Economic Forum.

Mendoza, A., G. Nayyar and R. Piermartini. 2018. "Are the "Poor" Getting Globalised?" Forthcoming in World Bank/WTO Trade and Poverty Reduction: New Evidence of Impacts in Developing Countries.

Miroudot, S., J. Sauvage, and B. Shepherd. 2013. "Measuring the Cost of International Trade in Services." Developing Trade Consultants. 
Monteiro, J. 2016. "Provisions on Small and Medium-sized Enterprises in Regional Trade Agreements." WTO Working Paper.

Nordås, H. 2016. "Services Trade Restrictiveness Index (STRI): The Trade Effect of Regulatory Differences." OECD. Trade Policy Papers.

OECD. 2018. "Agricultural Policy Monitoring and Evaluation 2018." OECD, Paris.

OECD. 2017. "Enhancing the Contributions of SMEs in a Global and Digitalized Economy." Meeting of the OECD Council of Ministers, June 2017.

OECD. 2013. "International Regulatory Co-operation: Addressing Global Challenges." OECD, Paris.

Oster, E. and B. Steinberg. 2013. "Do IT Service Centers Promote School Enrollment? Evidence from India." Journal of Development Economics.

Reyes, D. 2011. "International Harmonization of Product Standards and Firm Heterogeneity in International Trade." World Bank Policy Research Working Paper No. 5677.

Shepherd, B. 2007. "Product Standards, Harmonization, and Trade: Evidence from the Extensive Margin." World Bank Policy Research Working Paper Series 4390.

Spearot, A. 2016. "Unpacking the Long-Run Effects of Tariff Shocks: New Structural Implications from Firm Heterogeneity Models," American Economic Journal: Microeconomics.

Sykes, A. 2017. "Regulatory Consistency Requirements in International Trade." Stanford Law School, Working Paper No. 502.

UNCTAD. 2017. "World Investment Report 2017." United Nations Conference on Trade and Development. UNCTAD. 2015a. " World Investment Report 2015: Reforming International Investment Governance." United Nations Conference on Trade and Development.

UNCTAD. 2015b. "Key Statistics and Trends in Trade Policy." United Nations Conference on Trade and Development.

USITC. 2017. "Global Digital Trade I: Market Opportunities and Key Foreign Trade Restrictions." U.S. International Trade Commission. Publication 4716.

USITC. 2014. "Digital Trade in the U.S. and Global Economies, Part 2," U.S. International Trade Commission. Publication 4485.

Vidigal, G. 2017. "Why Is There So Little Litigation under Free Trade Agreements? Retaliation and Adjudication in International Dispute Settlement," Journal of International Economic Law.

Volpe Martincus, C., J. Carballo, and A. Graziano. 2015. "Customs." Journal of International Economics. World Bank. 2018. "E-Trade For Development: Opportunities, Challenges, and Policy Considerations for Developing Countries."

World Bank. 2015. "Low-income Developing Countries and G-20 Trade and Investment Policy."

World Bank and World Trade Organization. 2015. "The Role of Trade in Ending Poverty."

World Trade Organization (WTO). 2017. "20 Years of the Information Technology Agreement. Boosting Trade, Innovation and Digital Connectivity."

World Trade Organization (WTO). 2016a. "Advancing the Multilateral Trading System: Issues for Further Consideration." Discussion Paper for the G-20.

World Trade Organization (WTO). 2016b. "World Trade Report 2016: Levelling the Trading Field for SMEs."

World Trade Organization (WTO). 2015. "World Trade Report."

World Trade Organization (WTO). 2011a. "World Trade Report." 
World Trade Organization (WTO). 2011b. "Regulatory Cooperation Between Members." Background Note by the WTO Secretariat. G/TBT/W/340.

Wu, M. 2017. "Digital Trade-Related Provisions in Regional Trade Agreements: Existing Models and Lessons for the Multilateral Trade System." RTA Exchange. Geneva: International Centre for Trade and Sustainable Development (ICTSD) and Inter-American Development Bank (IDB). 